QUADERNS DE FILOSOFIA VOL. VI NÚM. 2 (20I9): 9 I-I 27

eISSN: 234I-3042 DOI: I0.7203/QFIA. 6.2.I6055

JOAN GIMENO-SIMÓ

Universitat de València

\title{
Semàntica i pragmàtica, contingut i context
}

Rebut: . Acceptat:

Resum: Aquest article té com a objectiu resumir els punts principals del debat sobre la divisió entre semàntica i pragmàtica. S'hi expliquen les tres principals postures dins la disputa i s'hi proporciona un esquema general per determinar quines teories encaixen a cadascuna d'elles. L'article conclou amb una breu discussió sobre la naturalesa de la noció de contingut i el seu rol al debat.

Abstract: The aim of this paper is to summarize the main lines of the debate about the semantics-pragmatics divide. The three main contenders in the dispute are explained, and a general schema for fitting theories into each of them is provided. This article concludes with a brief discussion on the nature of the notion of content and its role in this debate.

Paraules clau: minimisme, contextualisme, relativisme, contingut explícit.

Keywords: minimalism, contextualism, relativism, explicit content.

T A semàntica estudia el significAt lingüístic. La pragmàtica, per la L seua banda, sol ser caracteritzada com l'estudi de temes com ara els usos del llenguatge o els efectes del context sobre el significat, entre d'altres. Aquestes caracteritzacions són encara molt imprecises, però fan palès que estem tractant amb dues disciplines que comparteixen en gran mesura l'objecte del seu estudi, i que en conseqüència se solapen l'una a l'altra ben sovint. Aquest assaig està dedicat a estudiar aquest solapament i les postures que hom ha pres al respecte: repassarem les principals propostes que s'han plantejat per traçar la línia divisòria entre la semàntica i la pragmàtica, si és que se’n pot traçar cap, i provarem d'oferir un marc general per copsar les diverses maneres d'establir aquesta distinció. Com vorem, aquestes propostes depenen en última instància 
de la concepció que hom tinga d'aquests dos camps d'estudi, així com de conceptes clau com ara "significat" o "context".

Entre les postures divergents que han pres part en aquest debat les més conegudes i comunament acceptades son el minimisme, el contextualisme i el relativisme; les explicarem i detallarem a les tres primeres seccions. Les diferències que hi ha entre aquestes postures són a vegades nominals, però sovint amaguen discrepàncies insalvables en la manera d'entendre allò que volen explicar, fins al punt de discrepar pel que fa a les dades de què una teoria semàntica ha de fer-se càrrec. Val a dir, però, que cadascuna d'aquestes tres categories generals aixopluga tot un ventall de teories i de posicions intermèdies; a més, no és infreqüent que hom adopte postures diferents depenent del tipus d'expressions que estiga tractant —així doncs, sovint l'adopció de l'una o de l'altra per part d'un autor no reflecteix necessàriament una manera de concebre la separació entre semàntica i pragmàtica- .

En aquest assaig oferiré un marc general per entendre quan una postura compta com a minimista, contextualista o relativista (secció primera), i més endavant passaré a discutir-les i a fer-ne una comparativa, tot citant quins tipus d'evidència s'ha fet servir per argumentar-hi a favor i discutint com aplicar-les a casos concrets (seccions segona i tercera). Conclouré amb una breu discussió sobre la naturalesa de la noció de contingut i la seua relació amb el debat que ens ocupa (secció quarta).

\section{Context I ALlò ASSEverat}

La classificació d'una postura com a minimista, contextualista o relativista depèn, en essència, de la importància que aquesta atribuïsca a cadascuna de les dues tasques fonamentals que el context pot dur a terme. D'ençà de l'obra d'autors com ara David Kaplan (I977) i David Lewis (I980) ha esdevingut estàndard atribuir al context dos rols diferents, una dualitat ja reconeguda pel pare de la semàntica contemporània, Richard Montague (1970, 379). Seguint la terminologia de John MacFarlane (2003B; 2005) podem classificar aquest doble paper així: un rol post-semàntic consistent a determinar a quin aspecte de la realitat es correspon el contingut d'una expressió lingüística, i un rol semàntic consistent a determinar quin contingut ha estat asseverat. En termes generals, podem dir que una postura compta com a contextualista si atorga al context una funció semàntica molt important, mentre que les postures relativistes acostumen a donar més importància al paper post-semàntic. Les postures minimistes, en canvi, es caracteritzen per reconèixer un contingut mínim que no depèn del context en cap d'aquestes dues maneres. Vegem en què consisteix cadascun d'aquests rols. 
Hui dia és gairebé un truisme en filosofia del llenguatge que l'extensió d'una expressió (el conjunt d'objectes que hi cauen a sota) depèn d'alguna mena de paràmetre extralingüístic: la persona denotada per un ús de l'expressió "el quaranta-cinquè president dels Estats Units" dependrà de qui haja arribat a ocupar el despatx oval de la Casa Blanca en un determinat moment històric. Tanmateix, no sembla plausible que una propietat purament lingüística com és el significat d'una expressió puga variar en funció del resultat d'unes eleccions nord-americanes. El que açò vol dir és que el significat d'una expressió no ha de ser identificat amb la seua extensió, sinó més aviat amb una regla per determinar-ne l'extensió d'acord amb diverses situacions, tant de reals com de contrafactuals ${ }^{1}$. En aquesta mena de semàntiques, el significat cal identificar-lo amb una intensió: una regla (o, més acuradament, una funció) que determina l'extensió d'una expressió d'acord amb algun paràmetre extralingüístic, ja siguen aquests descripcions d'estats (CARNAP I 947), situacions (BARWISE i Perry I983) o, el més habitual, mons possibles (KRIPKE I 972).

Vet ací, doncs, una primera qüestió on el context esdevé rellevant: la de determinar l'extensió d'una expressió, ço és, aquell aspecte de la realitat a què es correspon la informació transmesa per aquesta. En el món real, "el quarantacinquè president dels Estats Units" es correspon amb Donald Trump, però hi ha situacions alternatives on denota Hillary Clinton; les expressions "animal amb ronyons" i "animal amb cor" tenen la mateixa extensió al món real, però reben valors distints si són avaluats en un món alternatiu. En última instància, la veritat o falsedat de la proposició expressada per un enunciat (és a dir, la veritat o falsedat d'allò dit $\mathrm{o}$ allò asseverat) dependrà del món possible, situació o descripció d'estat en què estiguem avaluant-la: l'enunciat "el quaranta-cinquè president dels Estats Units és un home" assevera una proposició que podria haver estat falsa si els esdeveniments històrics hagueren ocorregut altrament. Així doncs, si identifiquem la informació transmesa per una expressió amb la intensió d'aquesta, un rol del context consisteix a determinar a quin aspecte de la realitat es correspon aquesta informació. Aquest és, per tant, un rol post-semàntic: serveix per avaluar si allò asseverat és vertader o fals.

Tanmateix, aquest no és l'únic rol que el context pot exercir. L'obra dels autors esmentats més amunt ha fet palés que el paper que juga el context és doble: no només pot servir per avaluar si allò asseverat és vertader o fals, sinó

${ }^{1}$ Aquesta idea ja es troba latent a l'obra de Gottlob Frege (I 892), i eventualment va cristal-litzar en el desenvolupament de les semàntiques intensionals, introduïdes per Alonzo Church (195I) i Rudolf Carnap (I947). També és molt important l'obra de Marcus (I946) i Kripke (I959; I963A; I963в). 
també per determinar què és allò que es diu, ço és, per determinar la intensió que una expressió rep quan és emesa en un determinat context. Considereu enunciats com els següents:

(1) Jo he estat batlle de Morella

(2) Ella vol viatjar a la Xina

(3) Demà plourà

Imaginem dues emissions de l'enunciat (1), la primera per Ximo Puig i la segona per Blasco Ibáńez. El primer ha dit una cosa que és certa, i el segon una de falsa; en la mesura que cada emissió determina unes condicions de veritat distintes, sembla adient de dir que han asseverat proposicions diferents. En termes de proposicions estructurades russellianes, podem representar allò dit per cadascuna de les dues emissions d'(1) així:

(1a) <Ximo Puig, ésser batlle de Morella>

(1b) <Blasco Ibáńez, ésser batlle de Morella $>$

Per descomptat, (1a) i (1b) no són vertaderes en els mateixos mons possibles, ni en les mateixes situacions o descripcions d'estats: es tracta de dues proposicions (intensions) distintes, les condicions de veritat de les quals difereixen. Tanmateix, l'enunciat que hom ha fet servir per expressar-les ha estat el mateix, i amb els enunciats (2) i (3) ocorre una cosa semblant: la proposició que expressen variarà, respectivament, segons la persona que estiguem assenyalant i segons el dia d'emissió.

Allò característic d'aquests enunciats és que contenen expressions díctiques, ço és, mots el referent dels quals varia segons la circumstància d'emissió: "jo", "demà", "ell", "acî". El rol que juga el context en determinar el contingut d'aquests enunciats és ben diferent del que hem descrit més amunt: no es tracta d'avaluar si allò asseverat és vertader o fals, sinó més aviat de determinar què és allò asseverat — si hom vol avaluar si la informació transmesa és vertadera o falsa, primer cal esbrinar quina és aquesta informació-. Les condicions de veritat del que es diu en emetre els enunciats (1-3) variaran segons el context en què hom els emeta; per tant, podem dir que el context no juga ací un rol merament post-semàntic, consistent a determinar si allò asseverat és vertader o fals, sinó plenament semàntic, car és imprescindible per elucidar què ha estat expressat.

Així doncs, a la literatura sobre semàntica i pragmàtica hom acostuma a distingir entre el context d'emissió i el context d'avaluació. Una expressió feta servir en un context d'emissió particular té un contingut determinat; si és un enunciat, expressa una proposició. Aquest contingut o proposició, al seu torn, és un objecte abstracte amb propietats intensionals: és una constructe que pot correspondre's amb coses diferents, o ser vertader o fals, depenent del context o circumstàncies en què estiguem avaluant-lo. La imatge bàsica és la següent 
(adaptat de Schaffer 2008; Santorio 20 i 2; Westerståhl 20 i 2; i Rabern i BALL 20I9):

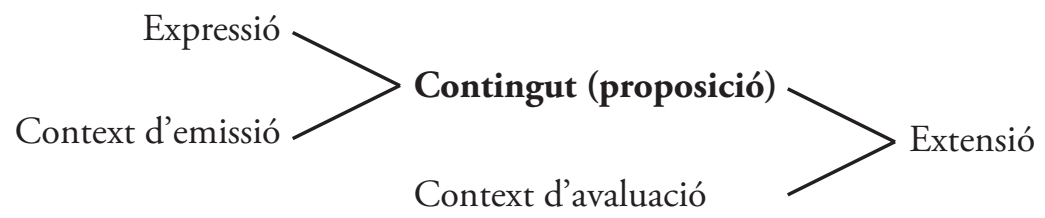

Un caveat que cal tindre present és que aquests contexts no han de ser concebuts com a situacions reals: són més aviat eines abstractes que el teòric fa servir per tal d'explicar tota mena de fenòmens lingüístics (vegeu BALL 20 I 7 per a una discussió). Açò vol dir que la seua relació amb la realitat no és tan directa com puga semblar, i que la seua composició exacta pot variar depenent de la teoria que estiguem defensant i dels fenòmens que voldrem modelar. Allò comú és tractar el context d'avaluació senzillament com un món possible, però molts autors hi incorporen paràmetres addicionals; Kaplan (I977), per exemple, pensava en els contexts d'avaluació, que ell anomenava circumstàncies, com a parells consistents en un món i un instant de temps, de manera que allò dit seria vertader o fals depenent no només de com siga el món sinó també del moment particular en què estiguem avaluant-ho ${ }^{2}$. De la mateixa manera, hom ha proposat tot un seguit de paràmetres que poden pertànyer al context d'emissió: parlants, oïdors, llocs, instants de temps o estàndards de precisió, entre d'altres, semblen rellevants a l'hora de determinar quina proposició ha estat expressada.

Tenint aquesta imatge bàsica en ment es pot formular un criteri inicial, que més endavant matisarem, per distingir les tres postures esmentades més amunt. El minimisme, també conegut com a "tradicionalisme", "invariantisme" o "literalisme", defensa que el nombre d'expressions que depenen del context d'emissió és mínim, i que a més estan sintàcticament marcades: es tracta dels díctics, i potser també altres elements amb funció gramatical, com la morfologia verbal. Dit altrament, un enunciat que no continga cap díctic expressa la mateixa proposició - té les mateixes condicions de veritat - en tots els contexts d'emissió. El principal adversari del minimisme és el contextualisme, que defensa exactament el contrari: la dependència contextual va molt més enllà dels díctics i afecta expressions de tota mena, de manera que és ben possible fer servir un enunciat no-díctic, no-el-líptic i no-ambigu per expressar proposicions distintes depenent del

\footnotetext{
${ }^{2}$ Aquesta postura sol anomenar-se "temporalisme", per contraposició a l'eternisme, que concep les proposicions com a quelcom que ja incorpora un temps i que per tant no varien depenent de en quin instant les avaluem.
} 
context d'emissió; aquesta dependència contextual generalitzada es deu a una intromissió de processos de caire pragmàtic dins del processament sintàctic i semàntic, fet que impedeix concebre la semàntica com una disciplina autònoma. El relativisme, per la seua banda, planteja una mena de tercera via, intermèdia entre les altres dues postures: com vorem, accepta moltes de les dades proposades tant per minimistes com per contextualistes, i es diferencia d'aquests últims perquè, en comptes d'explicar les dades problemàtiques apel.lant a una diferència en les proposicions expressades, prova d'acomodarles afegint més paràmetres al context d'avaluació, de manera que la veritat d'un enunciat (no allò que expressa) és relativa a tot un seguit de paràmetres que van més enllà d'un món possible i que els tradicionalistes normalment no acceptarien.

Un xicotet exemple pot ajudar a copsar la diferència entre aquestes tres postures. Imaginem que tot just després d'un congrés de filosofia té lloc un sopar, i hom hi emet l'enunciat $(4)^{3}$ :

(4) Tots els epistemòlegs estan prenent cafè

Deixant de banda la morfologia verbal, que ací resulta irrellevant, (4) no conté cap díctic; açò vol dir que, d'acord amb el minimisme, aquest enunciat expressa sempre la mateixa proposició, independentment del context en què s'emeta. Aquesta idea pot resultar una mica contraintuïtiva, car allò expressat literalment per aquest enunciat no és una proposició sobre els epistemòlegs que hi ha al sopar, sinó sobre tots els epistemòlegs de l'univers, i per tant diu quelcom que és òbviament fals. Així doncs, hi ha una discrepància entre el significat literal de (4) i el que el parlant volia expressar mitjançant l'emissió d'aquesta, fet que els minimistes acostumen a explicar tot apel-lant a fenòmens de caire pragmàtic, normalment subscrivint una distinció estricta entre allò dit i allò implicat, i tot dient que els judicis dels parlants no sempre capturen allò literalment expressat. Els contextualistes, per la seua banda, adoptarien tot un seguit d'estratègies per argumentar que (4), en el context en què ha estat usada, expressa una proposició més o menys equivalent a "tots els epistemòlegs d'aquest sopar estan prenent cafè". Els relativistes, en canvi, concedirien que (4) expressa el mateix independentment del context en què siga enunciada, però dirien que allò expressat no és quelcom vertader o fals de manera absoluta sinó en relació amb un seguit de paràmetres que inclouen no només un món possible sinó també d'altres, com ara un domini de quantificació, un instant de temps, etc. Allò que (4) expressa, doncs, no serà vertader depenent només de com siga el món, sinó també, per exemple, del conjunt d'individus rellevants en què calga fixar-s'hi.

\footnotetext{
${ }^{3}$ Per a una discussió general sobre el debat entre contextualisme, relativisme i minimisme en el context dels dominis de quantificació, vegeu Stojanovic (2008).
} 
Aquestes estratègies poden aplicar-se a tot un ventall de casos, i l'adopció de l'una o de l'altra té conseqüències en diversos temes, com ara la distinció entre la mentida i el mer engany o la discussió sobre la dependència contextual del verb "conèixer", ja clàssica en epistemologia ${ }^{4}$. En les dues seccions següents examinarem les principals dades que s'han fet servir per motivar cadascuna d'aquestes aproximacions a la semàntica i la pragmàtica, i explicarem en profunditat els seus postulats bàsics més enllà de l'esquema general - i a vegades no del tot acurat— que hem proporcionat més amunt.

\section{Minimisme i conteXtualisme}

El debat entre el minimisme i el contextualisme pot considerar-se com una continuació contemporània del debat clàssic entre les aproximacions formals a l'estudi del llenguatge i les teories basades en l'ús. La tradició formalista té les seues arrels a l'obra de filòsofs com ara Gottlob Frege, Bertrand Russell, Rudolf Carnap o Ludwig Wittgenstein a la primera etapa del seu pensament, mentre la segona l'encapçalen figures com el segon Wittgenstein i els representants de l'escola d'Òxford, notablement John Austin i Peter Strawon. El relativisme és una postura d'aparició més recent $\mathrm{i}$, malgrat que es pot considerar com una mena de síntesi entre les altres dues, també pot ser vista com una vessant del formalisme que es pren seriosament les dades oferides pel contextualisme i prova d'acomodar-les sense haver de renunciar als mètodes tradicionals. Al llarg d'aquesta secció i de la següent explicarem i confrontarem aquestes tres postures.

Amb excepcions, el minimisme es caracteritza per defensar l'ús d'eines formals, normalment provinents de la teoria de models $^{5}$, per estudiar la semàntica del llenguatge natural. La idea és associar cada element lèxic amb una entitat abstracta, el seu significat, de manera que el significat de les expressions més complexes quede determinat pel significat dels elements més simples que les composen i per la manera com aquests estan ordenats -el que normalment hom anomena "composicionalitat"-. El significat lingüístic és vist com a formalment tractable en tant que la dependència contextual és mínima: al parer

${ }^{4}$ El debat és sobre si el verb "conèixer" depèn o no del context d'emissió. Una defensa clàssica del contextualisme en epistemologia és Williams (I99I); vegeu també Williamson (2005) per a una defensa de l'invariantisme i el volum d'Ichiakwa (2017) per a una visió general del debat. El mot "contextualisme" va sorgir precisament arran de la disputa en epistemologia, i no va ser fins més endavant que Recanati (2004) el va adaptar per al debat que ens ocupa.

${ }^{5}$ En realitat és enganyós parlar de models en semàntica formal, ja que la relativització a models sol ser omesa per irrellevant; d'entrada, n'hi ha prou d'associar cada expressió amb un objecte conjuntista. Vegeu Glanzberg (2014). 
dels minimistes, com ja hem esmentat, les úniques expressions el contingut de les quals pot variar segons el context d'emissió són els díctics, i llur variabilitat pot ser tractada de manera més o menys sistemàtica mitjançant regles bastant simples ("jo" refereix al parlant, "ara" al moment en què hom parla, etc.).

Un exemple de minimisme molt simple, i que ens servirà per il.lustrar aquesta idea, ens el proporcionen els projectes davidsonians (DAVIDSON 1967), que tenen com a objectiu obtindre una manera sistemàtica d'associar cada enunciat del llenguatge estudiat amb la seua traducció al metallenguatge, generant així enunciats veritatius amb la forma següent:

(5a) L'enunciat 'La neu és blanca' és vertader si i sols si la neu és blanca

(5b) L’enunciat 'La neu és blanca i freda' és vertader si i sols si la neu és blanca i la neu és freda

(5c) L'enunciat 'Snow is white' és vertader si i sols si la neu és blanca

Aquesta traducció acostuma a poder fer-se mitjançant un enunciat homòfon del metallenguatge, un procediment que en la majoria de casos resulta trivial: només cal llevar-ne les cometes ${ }^{6}$. Hi ha, però, enunciats per als quals aquesta traducció homòfona no està disponible ni resulta tan trivial com sembla, fet que per als davidsonians és indicatiu que ens trobem davant d'un mot el contingut del qual depèn del context d'emissió. Aquest és el cas dels enunciats amb díctics:

(6a) 'Jo sóc brasiler' és vertader si i sols jo sóc brasiler

És correcte un enunciat veritatiu com (6a)? Hi ha una asimetria important entre (6a) i (5a): aquest últim prediu que cada ús de l'enunciat 'La neu és blanca' serà vertader si al món s'acompleix la condició que la neu és blanca, però la predicció de (6a) és que cada emissió de 'jo sóc brasiler' serà vertadera només en cas que Joan siga brasiler, en tant que és Joan mateix qui ha estipulat (6a). Açò és òbviament erroni: Lula da Silva hauria de poder fer servir aquest enunciat per dir quelcom de vertader. Així doncs, la regla que ens cal és més aviat així:

(6b) 'Jo sóc brasiler' és vertader si i sols si l'objecte $a$ és brasiler, on $a$ és el parlant

${ }^{6}$ Hem fet servir una teoria davidsoniana perquè resulta facil il-lustrar-hi el minimisme; hi ha, però, quelcom d'immediatament sospitós en aquesta mena de teories: quan hom assumeix la tasca d'oferir una teoria de com funciona el llenguatge, o qualsevol altre fenomen, és dubtós que les explicacions hagen de ser donades en llenguatge natural. Les teories científiques poden, en els seus inicis, fer servir variants tècniques del vocabulari quotidià, però aquesta mena de vocabulari no és el més adient i eventualment ha de ser deixat enrere (el mot "memòria" que fan servir els psicòlegs pot estar relacionat amb la seua contrapart quotidiana, però refereix a una construcció teòrica que permet dur a terme prediccions i explicar fets). Si fem servir el llenguatge objecte com a metallenguatge, hi ha el risc de caure en la il·lusió d'haver explicat el problema quan senzillament l'hem desplaçat o, pitjor encara, trivialitzat (GLANZBerg 20I4; YALCIN 20I8). 
Açò vol dir que no sempre és possible de procedir mitjançant traduccions homòfones al metallenguatge: per al cas dels díctics no n’hi ha prou amb llevar les cometes. Aquesta asimetria es veu reflectida en diversos fenòmens que, com vorem més avall, han estat considerats com els casos més favorables al minimisme: el-lipsi, anàfora, analiticitat, cancel-labilitat $\mathrm{i}$, fins a cert punt, discurs indirecte. Per als minimistes aquesta asimetria, o una que puga ser formulada de manera semblant, mostra que estem tractant amb una expressió el contingut de la qual depèn del context d'emissió.

Una de les dues obres de referència del minimisme, Insensitive Semantics, de Herman Cappelen i Ernst Lepore (2005), presenta una aproximació davidsoniana a l'estudi del llenguatge. Tanmateix, no tota postura minimista és davidsoniana; l'obra que dóna nom a aquest corrent, Minimal Semantics, d'Emma Borg (2004), presenta una aproximació més estàndard, on les expressions lingüístiques no són associades a la seua contrapart en el metallenguatge sinó a objectes formals que en modelen el significat; aquest enfocament s'acosta més als procediments habituals per a l'estudi d'altres aspectes del llenguatge, com ara la sintaxi a la tradició generativista, i de fet una de les motivacions de Borg és la de fer compatible la semàntica amb una teoria modular del processament lingüístic. Altres representants del tradicionalisme són Scott Soames (2002), Stefano Predelli (2005A; 2005B ${ }^{7}$ i, fins a cert punt, Kent Bach (200I) i Jennifer Saul (2013). Més enllà de les discrepàncies, tots aquests autors comparteixen una tesi fonamental que permet de classificar-los com a minimistes, i que podem formular així:

MINIMISME: el rol del context en la determinació del contingut explícit d'una emissió es limita a aportar allò necessari per tal d'obtindre quelcom que pot ser avaluat com a vertader o fals.

La idea és que l'enunciat mateix disposa d'uns buits que cal emplenar mitjançant informació contextual per tal d'obtenir una proposició; un cop dut a terme aquest procés, la resta d'efectes del context són relegats a la pragmàtica i no tenen cap mena d'efecte semàntic. Aquest procediment ha estat anomenat saturació (ReCanati 2004, 7-10) i sol ser caracteritzat com una tasca que va de baix cap a dalt ("bottom-up"): es tracta d'un procés obligatori, requerit per l'enunciat mateix i, en particular, per la seua sintaxi: el paper del context en la determinació del significat oracional es limita a fixar els referents dels díctics i a resoldre ambigüitats, anàfores i el.lipsis. Un cop açò s'ha dut a terme, el context deixa d'exercir cap mena paper semàntic, tot i que encara pot servir per determinar informació transmesa a nivell implícit. Una formulació alternativa de la tesi fonamental del minimisme podria ser la següent:

${ }^{7}$ La postura de Predelli (2005A; 2005B) és sovint classificada com a relativista; vegeu-ne la discussió més avall. 
MINIMISME*: la dependència contextual del contingut explícit d'una emissió està sintàcticament marcada.

Aquesta caracterització no és equivalent a la que hem proporcionat més amunt, i hi ha minimistes que hi estarien en desacord. Allò important, però, és que els minimistes no neguen la importància del context en determinar la informació transmesa, sinó només a l'hora de determinar el contingut literal transmès per un enunciat, ço és, allò explícitament asseverat. Quan hom parla transmet informació que va molt més enllà del que les seues paraules literalment signifiquen, un fenomen que es fa ben palès quan pensem figures retòriques com ara la ironia o la metàfora però que en realitat és gairebé omnipresent: la informació que hom comunica mitjançant una emissió variarà depenent de factors tan diversos com la informació prèvia de què disposen els participants en la conversa, les seues intencions, el to de veu o fins i tot l'accent. Res d'açò, però, no té efectes sobre el significat literal d'un enunciat. En general, els minimistes s'adhereixen a la distinció griceana entre allò asseverat i allò implicat (GRICE 196I; I975): si un matí que no he esmorzat m'adrece als meus companys de feina tot dient-los "em morc de gana", el contingut literal de la meua emissió és fals, tot i que a nivell implícit puc estar transmetent-los-hi quelcom de vertader.

Els contextualistes, en canvi, no veuen gaire clara la idea de significat literal independent d'allò que el parlant vullga transmetre (RECANATI 200I; 2004). La tesi fonamental del contextualisme consisteix a dir que l'efecte dels processos pragmàtics sobre allò asseverat explícitament per una emissió va més enllà de la saturació: aquest procediment de caràcter obligatori no proporciona una proposició dreta i feta, sinó que els participants en la conversa encara poden dur a terme, addicionalment, un procés de dalt cap a avall ("top-down"), no obligatori, on enriqueixen lliurement l'enunciat fins assolir un contingut que té sentit contextualment. Vegem-ne un exemple:

(7) Aquest llibre és difícil

Un minimista diria que tot el que cal per tal d'obtenir la proposició expressada per (7) és determinar quin és el referent del demostratiu "aquest llibre". El contextualista, però, aniria més lluny, i diria encara és possible enriquir aquest contingut fins assolir un proposició similar a la que hauríem expressat mitjançant un dels enunciats següents:

(7a) Aquest llibre és difícil de llegir

(7b) Aquest llibre és difícil de trobar

(7c) Aquest llibre és difícil d'enquadernar

El minimisme, però, no nega que una emissió de (7) puga comunicar proposicions com les que transmetrien $(7 \mathrm{a}-\mathrm{c})$. On hi ha, doncs, la discrepància, allò que separa una postura de l'altra? Vet ací el punt principal on minimisme i 
contextualisme es troben en desacord: l'existència del que Emma Borg (2004) anomena proposicions minimes. Un minimista sostindria que el contingut explícit, literal, d'allò emès per (7) és la proposició que hom pot obtindre mitjançant el procés de saturació: que $a$ és difícil, on $a$ és un llibre. Un contextualista, en canvi, consideraria que allò explícitament asseverat no es correspon amb aquesta proposició mínima, sinó amb un dels continguts que podem obtindre mitjançant procediments opcionals d'enriquiment pragmàtic: que $a$ és difícil de llegir, de trobar, d'enquadernar, etc. Per als contextualistes, una noció com la de proposició mínima expressada per (7) no té sentit en si mateixa, car no juga cap mena de rol en la comunicació, i només és intel.ligible com a noció derivada, dependent de la de contingut comunicat, el qual es correspondria amb (7a-c): les proposicions mínimes, si existeixen, no tenen cap rellevància psicològica. Els minimistes, en canvi, defensarien que (7a-c) no tenen res a vore amb el contingut explícit de l'emissió, sinó que es transmeten només a nivell implícit.

La discrepància és, doncs, sobre si el contingut explícit d'una emissió de (7) es correspon amb una proposició mínima (el resultat de la saturació) o més aviat amb un contingut pragmàticament enriquit. Per als contextualistes, els mecanismes pragmàtics no només expliquen com es determinen les implicatures, sinó que juguen un rol semàntic molt important, consistent a enriquir contextualment el contingut literal d'una emissió fins assolir-ne un contingut explícit més precís. Una de les teories contextualistes més importants, la teoria de la rellevància (Sperber i Wilson i986; Carston 2002), anomena "explicatura" a aquest contingut explícit que ha estat enriquit de manera opcional sense cap mena de mediació del significat lingüístic; (7a-c) en serien alguns exemples ${ }^{8}$. Si allò explícitament asseverat per un enunciat es correspon amb l'explicatura o amb alguna noció similar, no hi ha divisió de treball entre la semàntica i la pragmàtica: allà on els griceans estrictes sostindrien que aquella es fa càrrec del contingut explícit d'una emissió i aquesta altra

${ }^{8} \mathrm{Hi}$ ha minimistes, però, que han proposat nocions similars. El cas més conegut és el de la noció d" implicitura" de Kent Bach (I994; 200 I; vegeu CARSTON 2002, 170-83 per a una comparació entre totes dues nocions), qui defensa que hi ha enunciats sense díctics que nogensmenys expressen continguts semànticament incomplets:

(a) Josep està preparat

Aquest enunciat pot voler dir que Josep està preparat per fer l'examen, per ser ascendit, per eixir a fer una volta, per anar al llit, etc. Al parer de Bach, és necessari de completar aquest contingut si hom vol obtindre quelcom que es puga avaluar com a vertader o fals, però el fet que aquest enunciat no puga expressar per si mateix cap proposició no el converteix en sensible al context: sempre expressa el mateix. És arran d'açò que hi ha discrepància entre Bach mateix i altres autors (fonamentalment CAPPELEN i LePORE 2005; 2006, manuscrit; vegeu les rèpliques de BACH 2007, manuscrit-a i manuscrit-b) sobre si la proposta compta com a minimista o com a contextualista moderada. 
d'allò transmés implícitament, els contextualistes considerarien que hi ha una intromissió de la pragmàtica en els processos semàntics, ço és, en la determinació d'allò asseverat'. És per això que sovint també se’ls anomena "post-griceans" (JASZCZOLT 2007).

Una bona manera d'il.lustrar aquesta discrepància és fer servir la distinció entre la mentida i el mer engany ${ }^{10}$. Habitualment se sol admetre que per tal de mentir cal dir quelcom de fals; si hom enganya un altre mitjançant una emissió vertadera, no està de fet mentint. Vegem-ne un exemple: demà de matí tinc una reunió programada, i un amic em convida a anar al cinema a vore una pel-lícula que projecten demà de vesprada. A mi no m’abellix anar-hi, de manera que responc així:

(8) Demà tinc una reunió

Com que la reunió està programada per a demà de matí, no és cert que no puga anar al cinema a causa de la reunió; així doncs, la meua emissió ha servit per enganyar l'oïdor, car li he induït una creença falsa. Nogensmenys, el que he dit és literalment cert: demà tinc una reunió. Com que la mentida requereix que el contingut de la meua emissió siga fals, jo no he mentit, sinó que merament he enganyat. La raó per la qual aquests exemples ens interessen és que el minimisme i les diverses varietats de contextualisme acostumen a fer prediccions distintes sobre els valors de veritat del contingut explícit de les emissions que hi apareixen. Considereu, per exemple, un escenari com aquest: Carmesina diu a Tirant que fique el pollastre al forn per tal que el sopar estiga llest quan ella torne a casa. Tirant se n'oblida i, poc abans d'arribar a casa, Carmesina el telefona per tal de demanar-li si ha fet el que li havia encomanat. Aleshores té lloc la conversa següent:

(9) Carmesina: "Has ficat el pollastre al forn, tal com t'havia dit?"

— Tirant: "Sí, l'hi he ficat"

Intuïtivament, diríem que Tirant ha mentit, és a dir, que allò que ha asseverat és fals. Tanmateix, Tirant podria defensar-se dient que, contràriament al que sembla, el que ha dit és vertader: al llarg de la seua vida, ell ha ficat el pollastre al forn moltes vegades. Les propostes contextualistes provarien d'acomodar les intuïcions del parlants —ço és, la idea que Tirant ha mentitmitjançant un seguit d'estratègies per tal d'enriquir el contingut explícit de l'emissió, de manera que la proposició expressada per Tirant resultaria falsa: que ha ficat el pollastre al forn hui o que l'hi ha ficat després que Carmesina li ho diguera, etc. Els minimistes, en canvi, adoptarien l'estratègia de defensa

\footnotetext{
${ }^{9}$ Molts dels assaigs a Sperber i Wilson (2012) són recomanables com a introducció a aquesta idea.

${ }^{10}$ Agraïsc a Tobies Grimaltos i Sergi Rosell les discussions que hem mantingut sobre els exemples que il-lustren aquesta distinció.
} 
de Tirant: atès que no hi ha res al contingut literal de les seues paraules que explicite que l'ordre ha estat duta a terme en el moment requerit per Carmesina, la seua emissió no compta com a mentida ${ }^{11}$, tot i que potser haja aconseguit enganyar Carmesina mitjançant informació transmesa a nivell implícit. En termes generals, els jutges contextualistes condemnarien Bill Clinton per perjuri, mentre que els minimistes, malgrat retreure-li la manca de moral que mostra amb la seua emissió, conclourien que és innocent d'aquesta acusació (vegeu-ne la discussió a SAUL 2002; 2013) ${ }^{12}$.

La raó que els minimistes acostumen a adduir per explicar la tendència a classificar l'emissió de Tirant com a falsa és que els parlants sovint estan equivocats pel que fa al valor de veritat de les seues pròpies emissions, i que els arguments dels contextualistes no tenen en compte totes les variables: no aconsegueixen discernir si el que els parlants reporten és un judici envers allò asseverat o envers el contingut implícit (SAUL 2002; BORG 2010). Els parlants sovint fan servir enunciats que, com (4), expressen falsedats si els entenem literalment, i ho fan perquè d'una banda no en tenen accés a les condicions de veritat $i$, d'altra, es troben en una posició que els permet saber que l'oïdor serà capaç d'inferir el contingut desitjat. Els contextualistes poden respondre que aquest argument pressuposa la distinció entre significat oracional i significat del parlant, que és precisament el que ells rebutgen; de fet, el retret més comú dels contextualistes envers els minimistes és que la noció de proposició mínima, entesa com el con-

${ }^{11}$ Açò és discutible, ja que no només depèn de si hom és o no minimista sinó també de la teoria semàntica que defense. Per exemple, molts minimistes dirien que el contingut explícit de (9) sí que inclou una referència al moment present: està marcat mitjançant la morfologia verbal. De fet, el perfet de l'indicatiu sol ser considerat com un díctic en idiomes com el català o l'italià, on hi ha contrasts com els que il-lustren els exemples següents:

(9a) Hui he posat el pollastre al forn

(9b) \#Ahir he posat el pollastre al forn

(9c) Ahir vaig posar el pollastre al forn

(9d) \#Hui vaig posar el pollastre al forn

(9e) Enguany he posat el pollastre al forn

(9f) \#Enguany vaig posar el pollastre al forn

En català, el perfet de l'indicatiu només es pot fer servir en combinació amb díctics que assenyalen el moment present: (9a) i (9e) són gramaticals, però (9b) i (9f) no ho són; aquest contrast també es produiria si el díctic haguera estat "aquesta setmana" o "aquest segle". Els passats simple i perifràstic, al contrari, només es poden fer servir per seleccionar moments passats sense relació amb cap moment present, fet que explica que combinar aquest temps verbal amb díctics com "hui" o enguany" resulte en agramaticalitat. Així doncs, es podria adduir que Tirant, en fer servir el perfet d'indicatiu, ha asseverat explícitament que ha posat el pollastre al forn en algun moment del passat recent —és a dir, que ha mentit-.

${ }^{12}$ Açò no està del tot clar. Al cap i a la fi l'emissió de Clinton va ser "no hi ha cap relació impròpia", el significat literal de la qual sembla ser que no hi ha arreu del món cap mena de relació (sexual o d'altre tipus) illlícita. La majoria dels minimistes comptarien açò com a fals, fet pel qual Saul (2013) se'n distancia. 
tingut que pot recuperar-se a través d'operacions sintàctiques i sense cap mena d'interferència pragmàtica, no té realitat psicològica. S'ha dut a terme recerca empírica sobre si els parlants incorporen o no el contingut implícit a les condicions de veritat de la proposició expressada, i el ben cert és que els resultats no han estat tot concloents: per exemple, els experiments de Bezuidenhout i Cooper Cutting (2002) apunten a que tant la proposició mínima com l'enriquida són construïdes en paral.lel, tal com prediuen els minimistes, malgrat que la darrera és més facilment accessible; en canvi, les troballes de Breheny, Katsos i Williams (2006) són més favorables al contextualisme.

Una conseqüència de la postura contextualista és que hom pot fer servir un enunciat no-díctic, no-el-líptic i no-ambigu per transmetre, a nivell explícit, proposicions molt diferents depenent del context d'emissió. Els exemples clàssics d'aquesta idea ens els proporcionen els experiments mentals proposats pels pioners del contextualisme, com ara Chales Travis (I977) o John Searle (I980A). Travis ens fa imaginar un escenari en què una xiqueta, Pia, té a casa un auró de fulles rogenques $i$, tot pensant que el color natural de les fulles d'un arbre és el verd, decideix pintar-les d'aquest color. Un cop enllestida la tasca, Pia emet:

(10) Les fulles són verdes

L'enunciat (10) és vertader en aquesta situació. Tanmateix, més endavant Pia rep la visita d'un amic botànic que va a la recerca de fulles verdes per tal d'estudiar-les, i Pia emet, una altra vegada, (10); aquest cop Pia ha dit quelcom de fals. Pia ha fet servir el mateix enunciat per dir una cosa vertadera i una de falsa sense que l'estat de les fulles canviara, fet del qual Travis conclou que les condicions de veritat expressades per aquest enunciat són diferents en cada emissió: "verd" destria una propietat distinta en cadascun dels dos escenaris ("verd per fora", "verd natural", etc.). Searle, per la seua banda, proposa un experiment mental similar per argumentar que el verb "tallar" selecciona propietats diferents depenent de l'ocasió. Segons explica, l'acció associada al verb "tallar" és ben diferent quan tallem la brossa i quan tallem un pastís: si hom agafa un ganivet i fa talls verticals en l'herba tal com ho faria amb un pastís, la seua acció pot comptar com a "tallar la gespa" en moltes ocasions, però no si el que ho fa és un jardiner a qui li paguen per tallar-la. Casos com aquests han esdevingut tot un gènere literari ${ }^{13}$, amb exemples com el de François Recanati (200 I) amb l'espasa del lleó

${ }^{13}$ Travis i Searle són particularment prolífics. El primer (1985; I99I) ens narra, entre d'altres, les diverses maneres com una taula pot estar coberta de mantega, les diferents formes en què hom pot ser mariner i els distints casos en què un ànec pot pesar tres quilos; el segon (1978), per la seua banda, ens explica que ordres com la de tancar la porta o la de dur-me una hamburguesa no poden ser satisfetes només atenent al significat de les meues paraules, sinó que cal informació contextual addicional. Es podria argumentar que l'experiment mental de la cambra xinesa (SEARLE I980B) també constitueix un al-legat contra la idea que el significat puga ser tractat mitjançant operacions de caire sintàctic. 
(la que va servir per matar-lo o la que té en propietat?) o el d'Anne Bezuidenhout (2002) i el color de les pomes vermelles ("destriar pomes vermelles" és una acció diferent segons si el que volem és distingir-les de les verdes o destriar les que, a causa d'una malaltia, han esdevingut roges per dins).

La rellevància d'aquesta mena d'escenaris a l'hora de desenvolupar una teoria semàntica ha estat qüestionada (Predelli 2005B), i a més no tothom comparteix les intuïcions d'aquests autors. Tanmateix, aquests casos serveixen per il.lustrar la idea bàsica del contextualisme: de la mateixa manera que un enunciat amb díctics com (1) pot ésser usat per expressar proposicions distintes tot depenent del context d'emissió, un enunciat com (10), sense dependència contextual evident, també es pot fer servir per comunicar continguts amb condicions de veritat molt diferents. Un mot com "verd" depèn del context tant com qualsevol díctic: de la mateixa manera que "jo" pot seleccionar un individu distint depenent de qui l'emeta, "verd" també pot destriar propietats diferents tot depenent del context d'emissió (verd per fora, verd natural, etc.). És així, doncs, com el contextualisme encaixa a l'esquema que hem proposat a dalt: el context d'emissió juga un rol central en determinar la proposició expressada per un enunciat, més enllà de fenòmens com ara la desambiguació, l'el.lipsi, la dixi o l'anàfora. Ja hem assenyalat, però, que el procés mitjançant el qual una paraula com "verd" selecciona propietats diferents depenent del context no és completament anàleg al funcionament dels díctics com "jo"; per començar, la majoria dels contextualistes ho consideren com un procediment opcional. Les discrepàncies entre els diferents autors d'aquest corrent sorgeixen precisament ací: quin és el mecanisme mitjançant el qual es duu a terme aquesta tasca d'assolir una proposició contextualment enriquida.

Hi ha tot un ventall de propostes que podem classificar com a contextualistes per la manera com proposen tractar un determinat tipus d'expressions. El que hem descrit fins ara és el que hom sol anomenar "contextualisme radical": no hi ha res ni a la sintaxi ni al significat de les paraules que obligue a enriquir la proposició expressada, la qual és obtinguda mitjançant alguna mena de procediment psicològic aliè al llenguatge pròpiament dit. Tanmateix, hi ha altres postures que de vegades també són classificades com a contextualistes i que sí que incorporen aquesta dependència contextual a la sintaxi o la semàntica de les expressions; Borg (20I2) i Clapp (20I2) els hi donen el nom de "dicticistes" 14 . Un dicticista es caracteritzaria per, per exemple, proporcionar

${ }^{14}$ Traducció de l'anglés "indexicalist". De vegades hom fa servir en valencià mots com "indexicalitat" o "indexicalisme" per fer referència als fenòmens relacionats amb la dependència contextual, però açò sembla desencertat, en tant que la paraula "indexical", de la qual en serien derivats, no existeix en el nostre idioma. Una traducció més encertada és la que fa servir l'arrel "índex" per crear mots com "indèxic", d’on es podria derivar "indexicitat" i "indexicista". Tanmateix, allò que sembla més adient és fer servir mots que ja existeixen: "dixi”, "díctic” i els derivats que se’n puguen obtindre. 
una entrada lèxica per a "verd" com la de (10a) o per donar a " $a$ és verd" una forma lògica com la de (10b):

(10a) " $a$ és verd" és vertadera en el context $c$ si i sols si hi ha una propietat $P$ tal que $P$ compta com a verd en $c$ i $a$ té la propietat $P$

(10b) $a$ és verd $(P)$

Si el significat dels enunciats amb la forma " $a$ és verd" és modelat mitjançant (10a), la dependència contextual de "verd" ve donada per la semàntica del mot mateix: seleccionarà una propietat $\mathrm{o}$ una altra tot depenent del context. De manera equivalent, hom pot incorporar aquesta idea a la sintaxi, donant a l'enunciat " $a$ és verd" una forma lògica com (10b), on " $P$ " és una variable que agafa una propietat o una altra en cada context. Aquestes dues postures són essencialment idèntiques, i la dificultat rau a convertir-les en una tesi substantiva: explicar com es destria la propietat adient en cada context o com es dóna un valor a la variable. Trobem anàlisis d'aquest estil a Szabó (200 I), Rothschild i Segal (2009), i Kennedy i McNally (20I0). Un altre exemple clàssic de postura dicticista és l'anàlisi oferida per Stanley i Szabó (2000) per als dominis de quantificació:

(4a) Tots els epistemòlegs (d) han pres cafe

Ací " $d$ " és una variable lliure que selecciona un domini de quantificació contextualment destacat: els epistemòlegs de la facultat, del país, del sopar, etc. La raó per la qual Stanley i Szabó consideren que aquesta variable es troba present a la forma lògica de (4) és que aquests enunciats poden aparèixer subordinats a quantificadors, els quals han de lligar alguna variable (per a crítiques, vegeu CAPPELEN i LePORE 2002):

(4b) A tots els sopars de filòsofs on he estat, tots els epistemòlegs han pres cafè

(4c) [ $\forall d$ : $d$ és un sopar de filòsofs on he estat] ([ $\forall x: x$ és epistemòleg $(d)]$ ( $x$ ha pres cafe $)$ )

Aquests autors plantegen que les variables prenen un valor o un altre depenent del context d'emissió, i de resultes d'aquesta anàlisi el contingut dels enunciats com (4a), (10a) o (10b) varia d'un context a un altre tal com varia el contingut dels enunciats amb díctics.

Ara bé, a primera vista sembla que les anàlisis d'aquest estil contradiuen la idea central del contextualisme: en la mesura que en aquestes propostes les paraules o els enunciats contenen elements sintàctics o semàntics que en marquen la dependència contextual, podria semblar que es troben més aviat properes al minimisme, i de fet encaixen bastant bé a les dues definicions d'aquest que hem proporcionat més amunt. El ben cert és que les postures dicticistes són difícils de classificar; Borg mateixa (2010, 38) les considera més properes al tradicionalisme que no pas al contextualisme, i Recanati (2004) es reserva l'etiqueta "contextualisme" per a les teories que admeten dependència contextual no marcada 
per la semàntica ni la sintaxi, de manera que per comptar com a contextualista no n’hi hauria prou amb analitzar " $a$ és verd" com a (10a) o (10b). Tanmateix, els defensors de les postures dicticistes han estat classificats com a "contextualistes moderats" (CAPPELEN i LePORE 2005) o "contextualistes de corrent majoritari” (Stojanovic 2008). La raó per classificar-los així és que aquestes propostes tracten com a díctics expressions que no ho són de manera òbvia: paraules com "jo", "ací" o "aquest" pertanyen a un grup d'expressions on els mots "verd", "ploure" o "creure" no semblen estar-hi inclosos, i de fet, com ara explicarem, aquelles mostren un comportament molt distint al d'aquestes altres pel que fa a fenòmens com ara anàfora, el-lipsi o discurs indirecte. Així doncs, una proposta també pot comptar com a contextualista si proposa que el llenguatge conté "índexs ocults" o "díctics sorpresa" (CAPPELEN i Lepore 2005), que són postulats en base a la interpretació semàntica que hom vol assolir però sovint sense oferir cap mena de justificació gramatical per a aquest tractament.

Les propostes dicticistes sovint són criticades precisament per equiparar expressions de tota mena amb els díctics. Els contextualistes radicals admeten que expressions com "verd" o "ploure" poden agafar propietats diferents depenent del context, però troben equivocat diagnosticar aquesta mena de dependència contextual com a dixi - si ho fóra, resoldre aquesta dependència contextual seria una tasca obligatòria-. Els minimistes, per la seua banda, senzillament rebutgen que el contingut d'aquests enunciats depenga del context. Les raons esgrimides per aquests darrers autors, però fetes servir també per aquells, és que els díctics presenten unes propietats molt particulars quan interaccionen amb fenòmens com ara el discurs indirecte, l'anàfora, la cancel-labilitat o l'el-lipsi, els quals han estat considerats com a tests per saber si una expressió és dependent del context (CAPpelen i Lepore 2005, cap. 7). Considereu el contrast que es produeix quan traslladem les paraules destacades en negreta, "verdes" i "et", al discurs indirecte:

(11a) Pia adreçant-se a sa mare: "Les fulles són verdes"

(11b) Pia adreçant-se al seu amic botànic: "He dit a ma mare que les fulles són verdes"

(12a) Pia adreçant-se a sa mare: " $\boldsymbol{E} \boldsymbol{t}$ trobe a faltar"

(12b) Pia adreçant-se al seu amic botànic: "He dit a ma mare que $\boldsymbol{e} t$ trobe a faltar"

Tot i que el discurs indirecte no sempre és una bona guia, el contrast entre (11a-b) i (12a-b) mostra que un díctic com "tu" (o el seu derivat "et") no funciona de la mateixa manera que "verd". En traslladar un enunciat sense díctics a un context lingüístic de discurs indirecte, hom pot fer servir exactament les mateixes paraules que hauria utilitzat en discurs directe: la frase subordinada en (11b) és la mateixa que Pia emet en (11a), fet pel qual a (11b) Pia reporta correctament el que ella mateixa havia asseverat a (11a). Açò, però, no és possible en el cas dels 
enunciats amb díctics: si hom agafa les paraules exactes que Pia ha emès en (12a) i les posa sota l'abast d'un verb d'actitud proposicional, com ocorre en (12b), no reporta correctament el que Pia ha dit. La proposició que Pia ha expressat en (12a) és que troba sa mare a faltar, però açò no es correspon amb el contingut que s'atribueix a si mateixa en (12b), on el que assevera és que ha dit a sa mare que troba a faltar el seu amic botànic. Açò és així perquè "tu" agafa un referent distint depenent de a qui ens estiguem adreçant. Per tal de reportar correctament el contingut de Pia a (12a), cal que substituïm "et" per un mot diferent:

(12c) Pia adreçant-se al seu amic botànic: "He dit a ma mare que $\boldsymbol{l} \boldsymbol{a}$ trobe a faltar"

Els minimistes addueixen aquesta asimetria com a mostra que el contingut dels mots no-díctics no depèn del context d'emissió: la raó per la qual hem de canviar de paraula quan traslladem (12a) al discurs indirecte és que "et" agafa un referent distint depenent de a qui ens estiguem adreçant, i el mateix passa amb paraules com "açò", "ara" o "acî", que sovint cal substituir per "allò", "adés" o "allă". Un díctic com "tu" agafa un referent distint en cada context; si "verd" depenguera del context de manera anàloga, allò esperable seria que l'emissió de Pia en (11b) mostrara el mateix contrast, és a dir, que "verd" en aquest context destriara una propietat distinta a la que seleccionava en (11a), i que, en conseqüència, l'emissió de Pia fóra falsa de la mateixa manera que ho és (12b). Aquest no és el cas: independentment de si la conversa és sobre botànica o sobre cromatisme, hom pot emetre "Pia ha dit que les fulles són verdes" en tots els contexts per reportar el contingut de l'emissió original de Pia. En general, els díctics presenten un comportament molt diferent del de la resta d'expressions; vegem-ne un altre exemple:

(13) Pia: "Les fulles són verdes"

- Jaume: "Les fulles no són verdes"

(14) Pia: "Mon pare és a casa"

- Jaume: "Mon pare no és a casa"

En la conversa que té lloc en (13), Jaume contradiu Pia, però en (14) no es produeix cap mena de desacord ni de contradicció entre tots dos. Açò mostra que "verd" i "jo" — o els seus derivats "verdes" i "mon" — tenen un funcionament molt diferent: per tal de negar un enunciat sense díctics només cal afegir "no", tal com Jaume fa a (13), però açò no sempre és possible si hi ha díctics involucrats: a (14), Jaume no contradiu Pia. Aquests exemples mostren que és possible capgirar els experiments mentals de Travis i Searle per defensar exactament el contrari; al cap i a la fi, si jo faig talls verticals en un pastís i després isc al jardí i hi passe la màquina de tallar la gespa, (15) és vertadera:

(15) He tallat tant el pastís com la gespa

Quina propietat destria el mot "tallar" en aquesta emissió? Ha de ser una propietat que tant l'acció de tallar la gespa com el pastís tinguen en comú; si 
Searle tinguera raó quan diu que aquest verb selecciona propietats diferents depenent del context, no hi hauria cap mena de context on (15) fóra vertadera. Altres fenòmens lingüístics com ara l'anàfora, l'el-lipsi, la copredicació i la cancellabilitat també semblen jugar en contra de tractar paraules com "difícil" com a dependents del context. Si "difícil” poguera destriar una propietat diferent en cada context, emissions com les següents no semblarien possibles:

(16) Aquest llibre és difícil, però trobar feina digna ho és més

(17) Aquest llibre és difícil, i els exàmens finals també

(18) Tant la marató com el llibre són difícils

(19) Aquest llibre és difícil, però és facil de trobar

L'enunciat (16) conté un pronom anafòric, "ho", i per tal de resoldre aquesta anàfora cal atribuir al llibre i a trobar feina la mateixa propietat: ser difícils. Açò no seria possible si la propietat que prediquem del llibre és la de ser "difícil de llegir"; amb l'el-lipsi de (17) podem dur a terme un raonament anàleg. L'exemple (18), anàleg a (15), atribueix a la marató i al llibre la mateixa propietat, fet que no encaixa bé amb la idea que "difícil" agafe una propietat o una altra segons el context ${ }^{15}$. La cancel-labilitat també és una dada important: (19) no és contradictòria en cap context, però hauria de ser-ho si en alguns d'ells "difícil" destriara la propietat "difícil de trobar". Aquesta asimetria entre díctics i no-díctics reflecteix la que hi havia al si de les teories davidsonianes respecte a la impossibilitat de donar el significat d'un enunciat amb díctics mitjançant la seua traducció homònima al metallenguatge.

Val a dir, però, que hi ha casos més favorables per als dicticistes. En la teoria estàndard (СhOMSKy 1986; i995; Heim i Kratzer I998 per a l'estàndard en semàntica) hom sol assumir que alguns enunciats contenen elements sintàctics que no són reflectits a nivell fonètic i que, a més, es comporten com si foren pronoms. Aquest és, per exemple, el cas de les traces de moviment sintàctic o els sintagmes $\mathrm{PRO}^{16}$, els quals li semblen molt a la idea d'índexs ocults.

${ }^{15}$ Vegeu també els casos de copredicació a Pustejovsky (1995) i Chomsky (2000).

16 "PRO" (pronunciat "pro gran") no és més que el subjecte dels verbs en infinitiu o gerundi: "El ratolí ${ }_{1}$ vol $\mathrm{PRO}_{1}$ menjar formatge". Han d'estar coindexats amb el seu antecedent anaforic perquè altrament no és possible d'assolir la interpretació desitjada: que el ratolí $x$ vol que $x$ menge formatge. Els idiomes com el valencià o el castellà, amb tendència a elidir el subjecte de molts enunciats, contenen un altre pronom fonèticament nul: "pro" ("pro xicotet"), que fa de subjecte en

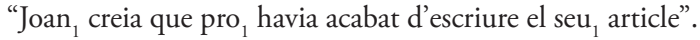

Pel que fa a les traces, són senzillament el resultat del moviment sintàctic. Per exemple, una qüestió com "què has fet?" conté un element desplaçat, l'objecte directe, que no ocupa la seua posició sintàctica habitual ("has fet què"). Hom acostuma a dir que els elements moguts deixen traces de moviment: "què has fet $\mathrm{t}_{1}$ ", on la $t$ marca la posició inicial de l'objecte directe. Aquests elements són fonèticament nuls, però tenen efectes sobre la interpretació de l'enunciat: per exemple, l'enunciat anglès "who do you want to shot?" és ambigu entre dues interpretacions ("a qui vols disparar?" i "qui vols que dispare?"), però "who do you wanna shot?" no ho és (només pot voler dir "a qui vols disparar?"), fet que s'explica perquè "wanna" pot abreujar "want to" però no "want $t$ to". 
D'altra banda, hi ha paraules que hom no classificaria immediatament com a díctics però que passen els mateixos tests: aquest és el cas, per exemple, dels anomenats "verbs díctics de moció" (BARLEW 2017), que inclouen paraules com "anar" i "vindre" o els mots castellans "traer" i "llevar". Aquests són bons candidats, doncs, per ser considerats com a "díctics sorpresa”. D’altra banda, també hi ha predicats les propietats inferencials dels quals semblen indicar que hi ha quelcom més a la forma lògica dels enunciats que els contenen: arran de l'enunciat "aquest gos és un dòberman i és teu" puc inferir "aquest gos és el teu dòberman", però a partir d'"aquell gos és pare i és teu" no és possible d'inferir "aquell gos és el teu pare" (PIETROsKi 2008). Finalment, la morfologia verbal es comporta de manera anàloga als pronoms personals en aquesta mena de tests (Partee i974; Kratzer 1998), fet pel qual hom sovint classifica com a díctics el temps, mode, aspecte i veu verbals.

Els contextualistes radicals, per la seua banda, poden eludir aquesta mena de crítiques dient que aquests fenòmens de caire lingüístic no invaliden la seua tesi, la qual al cap i a la fi consisteix a dir que el context intervé encara que no hi haja res al llenguatge que en faça obligatòria la intervenció: no és que la dependència contextual de (16-19) siga equivalent a la dixi, sinó que allò que aquests enunciats expressen, si és que expressen res per si mateixos, no només pot ser completat mitjançant un procediment com la saturació, sinó que a més pot ser alterat i retorçat a voluntat fins assolir la interpretació adient. Si açò és així, però, no està gaire clar per què les teories contextualistes han de resultar d'interès per al lingüista, que al capdavall el que busca no és una teoria general de la comunicació sinó més aviat una teoria sistemàtica sobre el funcionament llenguatge natural, ço és, dels mecanismes que explicarien, entre d'altres, les asimetries que hem assenyalat. Una crítica comuna dels tradicionalistes envers els contextualistes és, precisament, la d'atribuir a la semàntica el rol d'explicar qüestions que es troben més enllà del seu abast, com ara assumptes relacionats amb la comunicació (Borg 2004; Predelli 2005B).

\section{El TERCER EN DisCòrdia: EL RELATIVISME}

El minimisme sovint fa prediccions que no s'ajusten als judicis dels parlants, i explica aquesta discrepància fent al-lusió a la distinció griceana entre asseverar i implicar. Els contextualistes miren de fer justícia a les intuïcions dels parlants, però ho fan postulant una dependència contextual que o bé no casa amb l'evidència lingüística disponible (en el cas dels dicticistes) o que no resulta d'interès per a l'estudi del llenguatge pròpiament dit sinó que té més a vore amb una teoria general de la comunicació (contextualistes radicals). El 
relativisme, com hem dit més amunt, pot ser vist com una mena de via intermèdia entre tots dos: accepta els arguments dels contextualistes i prova d'oferir una manera sistemàtica de predir les intuïcions dels parlants, però alhora mira de preservar una noció de contingut que no entre en conflicte amb l'evidència lingüística. L'estratègia per aconseguir-ho consisteix a donar més importància al context d'avaluació, normalment afegint-hi més paràmetres a banda d'un món possible — tot i que, com vorem, amb açò encara no n'hi ha prou per comptar com a relativista-.

Una bona manera d'il.lustrar els principis bàsics d'aquesta postura consisteix a discutir una de les seues motivacions: el desacord sense culpa (KöLBEL 2004; LASERSOHN 2005; STOJANOviC 2007; SChaffer 2008). Quan hom està en desacord amb algú altre, la disputa acostuma a poder ser resolta, senzillament, mirant com són les coses en realitat: si vostè opina que el nombre d'arbres de l'avinguda Blasco Ibáńez és parell i jo, per contra, trobe que ha de ser senar, tot el que ens cal és baixar al carrer i comptar-los. Tanmateix, hi ha un tipus de desacord que sol ser expressat mitjançant enunciats que no semblen tan facilment verificables, ja que expressen gusts estètics, opinions polítiques o postures morals. Per exemple, jo puc estar en desacord amb (20):

(20) Les pomes fan bon gust

És plausible d'assumir, amb el contextualista, que (20) no expressa cap proposició absoluta amb unes condicions de veritat determinades; al cap i a la fi, no se sap ben quin és el procediment objectiu que caldria dur a terme per esbrinar si és vertadera o falsa. L'estratègia del contextualisme consistiria a dir que (20) expressa un contingut més ric, plausiblement un contingut a les condicions de veritat del qual el parlant o l'oïdor hi puguen tindre accés, és a dir, un contingut com el que normalment expressaríem mitjançant $(20 \mathrm{a})^{17}$ :

(20a) Al meu parer, les pomes fan bon gust

Açò vol dir que quan hom emet un enunciat sobre gusts estètics està en realitat parlant sobre els seus propis gusts —o potser sobre els de la seua comunitat o cultura- L La raó per la qual els relativistes troben problemàtica aquesta proposta és que faria impossible que els participants de la conversa estigueren en desacord entre ells, per la senzilla raó que cadascú estaria parlant d'una cosa distinta. Imaginem la següent conversa:

(20b) Hèlena: "Les pomes fan bon gust"

- Paris: "No, no en fan"

Aquesta conversa involucra el que pareix un cas legítim de desacord: a Hèlena les pomes li semblen gustoses, però Paris en contradiu l'afirmació per-

${ }^{17}$ Per descomptat, no tots els contextualistes dirien açò, ni tampoc acceptarien que qualsevol emissió d'aquest enunciat expressa aquesta proposició. Açò és més aviat una caricatura del contextualisme que he fet servir per motius expositius. 
què a ell no li ho semblen. D'entrada tots dos tenen raó i no hi ha manera de resoldre la disputa. D'acord amb el contextualista, però, l'emissió d'Hèlena en aquesta conversa comunica un contingut enriquit: que les pomes, al parer d'Hèlena, fan bon gust. Per descomptat, Paris no està en posició de negar aquest contingut: qui millor que Hèlena mateixa per saber què és el que a Hèlena li agrada? Paris, de fet, no estaria negant l'afirmació d'Hèlena, sinó que en realitat només parlaria sobre si mateix, de manera que la seua emissió tindria un contingut com "al parer de Paris les pomes fan bon gust". En conseqüència, Hèlena i Paris no es troben en desacord, sinó que més aviat estan mantenint el que podríem anomenar un "diàleg de sords": estan parlant de coses distintes. Açò és perquè els enunciats com (20), per al contextualisme, expressen coses diferents per a cada parlant; un cas anàleg serien, novament, els enunciats amb díctics:

(21) Ramon: "(Jo) sóc filòsof"

— Ausiàs: "No és cert, (jo) no sóc filòsof"

L'intercanvi que té lloc a (21) no sembla gaire encertat: Ausiàs no aconsegueix negar el que Ramon ha dit, i de fet ni tan sols està parlant sobre el mateix tema. Sembla, doncs, que hi ha una asimetria entre aquest intercanvi i l'altre, perfectament legítim, que té lloc en (20b). La idea que un enunciat com (20) puga expressar proposicions diferents depenent del parlant, de la mateixa manera com "jo" agafa individus distints en cada emissió, té com a resultat que cadascun dels participants en la conversa està parlant sobre el seu propi gust estètic, de la mateixa manera com cada participant de la conversa en (21) parla sobre la seua pròpia professió; aquesta manca d'un tema comú de conversa converteix els desacords en diàlegs de sords.

Cal, doncs, trobar una manera d'aconseguir que enunciats com (20) expressen el mateix contingut per a tots els participants de la conversa, però que alhora permeta explicar per què tant Hèlena com Paris puguen tindre raó en (20b). La solució típica del relativisme consisteix a dir que el context en què estem avaluant l'enunciat no consta només d'un món possible, sinó també d'alguna mena d'estàndard estètic: un individu, una cultura o una època determinats; podem anomenar aquest paràmetre "jutge". Així doncs, els enunciats estètics no són vertaders només en relació amb com siguen les coses (és a dir, en relació amb un món possible) sinó també amb el gust estètic d'un determinat jutge. A (20b), Hèlena avalua el contingut de (20) en el món real i d'acord amb el seu propi gust, obtenint com a resultat la veritat (és cert que al món real, d'acord amb Hèlena, les pomes fan bon gust), mentre que Paris avalua el mateix enunciat al mateix món però d'acord amb un jutge diferent, ell mateix, i de resultes d'açò obté la falsedat. Totes dues emissions, però, tenen el mateix contingut (que les pomes fan bon gust), i el fet que s'obtinguen resultats distints es deu a que són avaluades en paràmetres diferents. 
Aquesta estratègia no només és aplicable a enunciats amb un component subjectiu, sinó també a molts altres casos. Per exemple, un relativista diria que (4) expressa sempre el mateix contingut, però que aquest contingut no és una proposició absoluta que és vertadera o falsa només en relació amb com siga el món, sinó que només pot prendre un valor veritat un cop hem determinat un domini de quantificació adient: serà vertadera si l'avaluem en el món $w$ i el domini que consta dels comensals del sopar, però falsa si l'avaluem en el mateix món però un domini de quantificació diferent — diguem-ne, el domini consistent en el personal investigador de la Facultat de Filosofia de la Universitat de València- Així doncs, els continguts dels enunciats sense díctics no varien d'una emissió a l'altra, però la seua veritat és relativa a un seguit de paràmetres més complex que el que els minimistes acostumen a postular. Una cosa semblant es pot dir de (22):

(22) Plou

Novament, és difícil defensar que la veritat de (22) només és relativa a un món possible: dins d'un mateix món pot haver-hi pluja a Londres i bon oratge a València. En conseqüència, el relativista dirà que (22) és vertader no només en relació amb un món possible sinó també amb un lloc d'avaluació. Aquesta estratègia presenta un avantatge sobre l'opció contextualista (cf. Perry I998), que diria que el contingut de (22) variarà segons el context d'emissió, de manera que depenent de si l'emetem a Lisboa o a París expressarà la proposició que plou a Lisboa o que plou a Paris. Si no es fa cap mena d'ajustament teòric addicional, l'anàlisi contextualista impossibilita distingir (22) de (22a):

(22a) Ací plou

El relativisme pot explicar facilment el contrast entre (22) i (22a): qualsevol emissió de (22) feta a Tòquio expressa, senzillament, la proposició que plou, i aquesta proposició, al seu torn, pot ser vertadera a Moscou i falsa a Santiago de Xile. Tanmateix, (22a) conté un díctic el valor semàntic del qual depèn del lloc d'emissió, de manera que si l'emetem a Tòquio expressarem un contingut ben diferent: que està plovent a Tòquio. Per descomptat, la veritat d'aquesta darrera proposició és independent del lloc d'avaluació: no té gaire sentit dir que la proposició que a Tòquio plou és vertadera a Madrid però no a Los Angeles.

El contextualisme es caracteritzava per postular una alta variabilitat en els continguts que hom pot asseverar mitjançant un sol enunciat, però aquests continguts, un cop determinats, eren vertaders o falsos de manera absoluta. El relativisme fa el moviment contrari: en comptes de postular una alta variabilitat en les possibilitat d'asseveració de continguts, la postula en les condicions de veritat dels mateixos. És així com els relativistes aconsegueixen mantindre una noció de contingut que no varia d'una emissió a una altra i, alhora, fan 
les prediccions que els contextualistes volien assolir: per exemple, que (4) és vertadera en la situació que hem descrit. Així, els relativistes també marquen distància amb el minimisme pel que fa a les dades que una teoria semàntica ha d'explicar: els minimistes haurien dit que (4) és falsa però que es pot fer servir per transmetre, a nivell implícit, quelcom de vertader, mentre que els relativistes fan costat al contextualisme pel que fa a les dades dient que (4) és vertadera.

Un altre punt on els relativistes semblen discrepar dels minimistes és en la noció de contingut: aquests continguts que els relativistes postulen no es corresponen amb la noció tradicional de proposició, que sol correspondre's amb un terme tècnic per designar proposicions metafísiques — conjunts de mons possibles o, alternativament, funcions de mons possibles a valors de veritatPodem anomenar-los, doncs, "proposicions relativitzades". Ara bé, hi ha cap diferència real entre una postura i l'altra? Al capdavall, el minimisme és motivat per dades lingüístiques més que per qüestions com ara la informació comunicada o el contingut mental dels parlants; no és estrany, doncs, que molts dels seus defensors contemporanis hagen provat a deslliurar-se de nocions filosòficament carregades com la de proposició metafísica i hagen adoptat maneres distintes, més relaxades, de concebre el contingut, les quals s'assemblen molt al que esperaríem d'una proposició relativitzada.

La proposta de Predelli (2005A; 2005B), per exemple, és qualificada per ell mateix com a tradicionalista, però sovint se l'emmarca com a relativista $\left(\right.$ MacFARLANE 2007) ${ }^{18}$, en tant que relega la dependència contextual a la postsemàntica. Predelli troba que les crítiques envers les teories tradicionals sovint es deuen a una manera específica de concebre l'aparell teòric que es fa servir en semàntica: nocions com ara "món possible", "contingut" o fins i tot "context" tenen una càrrega filosòfica que ha dut molts autors a atribuir a aquesta disciplina objectius que cauen fora del seu abast. És per això que proposa que els paràmetres d'avaluació no s'entenguen com a mons possibles sinó més aviat com a descripcions més detallades, semblants a les situacions de Barwise i Perry (1983). Aquestes tenen l'avantatge de no estar filosòficament carregades, i són tan útils com els mons possibles a l'hora de tractar assumptes que sí que cauen sota l'abast de la semàntica, com ara l'analiticitat, l'anàfora o la conseqüència lògica. Altres defensors paradigmàtics del minimisme també rebutgen que la semàntica haja de tractar amb qüestions metafísiques o amb nocions com la de contingut mental (Borg 2004; CaPpelen i Lepore 2005). Si açò és així, sembla que no hi ha cap necessitat de donar als mons possibles cap mena d'interpretació filosòfica ni de concebre'ls com a "possibilitats màximes" ni res de

${ }^{18}$ McFarlane (2007) proposa inicialment el nom "contextualisme no-díctic" per a la proposta de Predelli i la seua pròpia. L'etiqueta "relativisme" ha estat més endavant aplicada a aquestes teories. 
semblant; açò vol dir que se'ls pot entendre d'una manera molt similar a com el relativista concep els contexts d'avaluació: el conjunt de paràmetres necessaris per avaluar la veritat d'una emissió.

Així doncs, els minimistes poden relaxar la seua postura fins trobar-se en posició de fer les mateixes prediccions que les teories relativistes i contextualistes, però d'entrada sembla que aquesta versió aigualida del minimisme col-lapsa amb el relativisme. Hi ha, tanmateix, una diferència fonamental entre aquesta i aquella: la noció de veritat. El fet de relativitzar els valors semàntics dels enunciats a dos contexts distints fa possible de definir la noció de veritat de diverses maneres: pot ser una propietat dels enunciats i ser relativa al context d'emissió i d'avaluació, pot ser una propietat dels continguts i ser relativa als contexts d'avaluació, o pot ser una propietat de les emissions i no ser relativa a cap paràmetre (vegeu MACFARLANe 2003 B i STOJANOviC 2008). Els relativistes sovint adopten la primera d'aquestes, ço és, la noció triàdica de veritat:

VERITAT-3: Un enunciat $p$ és vertader únicament en relació amb un context d'emissió $e$ i un context d'avaluació $a$

Adés hem esmentat, però, que els contexts d'emissió i d'avaluació són constructes teòrics que consten de diversos paràmetres seleccionats en base als fenòmens que vullguem modelar. Açò vol dir que molts d'aquests paràmetres poden coincidir: ja hem vist que per tal d'avaluar (22) i (22a) ens cal afegir un paràmetre de lloc tant al context d'emissió com al d'avaluació. Aquesta manera de concebre els contexts permet definir, per a cada context d'emissió $e$, el que podem anomenar el "context d'avaluació destacat per $e$ " o la "circumstància destacada per $e$ ": el context d'avaluació que s'obté copiant els paràmetres que trobem en $e$. Considereu el següent exemple: imaginem que a la nostra teoria els contexts d'emissió són modelats com una quàdrupla que consta d'un parlant, un món possible, un temps i un lloc, mentre que els d'avaluació són concebuts com un parell consistent en un món i un temps. En aquest cas, podem agafar un context d'emissió com <Carnap, $w_{1}, 1947$, Los Angeles> i definir-ne el context d'avaluació destacat com $<w_{1}, 1947>$. En termes generals, per a cada context d'emissió $e$ és possible de definir-ne aquesta circumstància d'avaluació privilegiada que podem simbolitzar com $a_{\mathrm{e}}$. El fet de poder definir aquesta noció és interessant perquè ens permet de reduir la noció triàdica de veritat a una de diàdica, on tot el que ens cal per obtindre veritat o falsedat és tindre un enunciat en un context:

VERITAT-2: Un enunciat $p$ és vertader-2 en un context d'emissió $e$ si és vertader- 3 en $e$ i en el context d'avaluació destacat $a_{e}$, on tots els paràmetres d' $a$ s'obtenen arran dels que hi ha a $e$.

Aquesta noció de veritat és, al parer de Kaplan (1977), la que importa per a qüestions lògiques: al seu sistema LD, la validesa és definida com a 
VERITAT-2 en tots els contexts (i tots els models). La idea que cada context d'emissió en privilegia un d'avaluació és la principal diferència entre el minimisme i el relativisme: per al minimista, quan hom emet un enunciat en un determinat context expressa un contingut al qual ja se li pot assignar veritat o falsedat (tot i que podria haver estat fals en altres circumstàncies), mentre que el relativista, que no admet els contexts d'avaluació destacats, troba que encara no és possible d'assignar veritat o falsedat a aquest contingut, car encara resta trobar un context adient per avaluar-l'hi. És per aquest motiu pel que adés hem esmentat que per tal de comptar com a relativista en relació amb un tipus d'expressions no n'hi ha prou amb afegir a la circumstància d'avaluació un paràmetre del qual aquesta expressió depenga, car un minimista o un contextualista també poden fer-ho. El que cal per tal de comptar com a relativista en relació amb un tipus d'expressió és que el valor semàntic d'aquesta depenga d'un paràmetre del context d'avaluació per al qual el d'emissió no en determine cap valor destacat.

Aquesta idea no només té efectes sobre qüestions com la conseqüència lògica o la validesa ${ }^{19}$, sinó que també serveix per explicar la dinàmica conversacional. Considerem un problema clàssic que el relativisme ha revifat recentment: els futurs contingents (MACFARLANE 2003A). Intuïtivament sembla que el contingut expressat per (23) no és encara ni vertader ni fals:

(23) Demà hi haurà una batalla naval

Per tal d'obtindre el contingut de (23) cal fixar el valor del díctic "demà", $i$ açò es duu a terme inserint la sendemà del dia d'emissió dins la proposició expressada: si el paràmetre de temps del context d'emissió és el vint d'octubre, (23) expressa la proposició que el vint-i-u d'octubre tindrà lloc una batalla naval. Un cop determinat aquest contingut, hom pot demanar-se si (23) és vertadera o falsa. En aquest cas, però, la idea kaplaniana que la veritat és una propietat dels enunciats en un context d'emissió sembla problemàtica: (23), emesa el vint d'octubre, serà vertadera-2 si i sols si la proposició que el vint-i-u d'octubre hi haurà una batalla naval és vertadera el vint d'octubre. D'entrada, açò contradiu les intuïcions que hem esmentat adés: el vint d'octubre aquesta proposició encara no és ni vertadera ni falsa. En canvi, aquesta intuïció és facil d'acomodar dins la concepció relativista de la veritat: el context d'emissió no determina el context en què hem d'avaluar (23), sinó que encara és possible de seleccionar-ne un de més adient — presumiblement, un de posterior al dia vint-i-u- Vet ací, doncs, el tret central de les propostes relativistes: emetre un enunciat en un context determina un contingut, però amb açò encara no

${ }^{19} \mathrm{Al}$ sistema de Kaplan, per exemple, "Plou" és conseqüència lògica de "Plou ara"; aquesta inferència, però, no és vàlida en els marcs relativistes. Vegeu MacFarlane (2003B), Predelli i Stojanovic (2008) i Predelli (2012). 
estem en posició per poder avaluar aquest contingut com a vertader o fals, perquè encara resta seleccionar els paràmetres adients per dur a terme aquesta avaluació.

Aquesta idea, però, es pot implementar de diverses maneres. Fins ara hem descrit una postura relativista genèrica, però hi ha altres maneres d'explicar per què la veritat d'una emissió pot ser relativa a paràmetres diferents per a cada parlant. Hom pot, per exemple, mantindre una noció de veritat similar a la kaplaniana, on el context d'emissió sí que determina la circumstància que cal fer servir per avaluar l'emissió, però dir que cadascun dels participants en la conversa disposa d'un context d'emissió diferent. Una altra opció és la de relativitzar el contingut d'una emissió en comptes de la seua veritat: hom pot adoptar una noció tradicional de proposició com una funció de mons possibles (i res més) a valors de veritat, però dir que quina siga aquesta funció dependrà d'un seguit de fets del món, i que aquests fets són relatius — aquesta postura seria un relativisme metafísic- . Finalment, també és possible explicar aquesta relativització si considerem que l'extensió de les expressions no depèn dels dos contexts que hem estat tractant fins ara sinó també d'un tercer: podem dir que cada context determina la seua pròpia circumstància destacada, però que a banda del context d'emissió i la seua circumstància encara hi ha un context d'avaluació que és diferent d'aquesta última. En la majoria dels casos aquestes diferències són una mera qüestió de formalisme i no suposen cap diferència quan es considera les teories extensionalment, però sí que poden reflectir una manera particular de concebre filosòficament les nocions que es fan servir.

Algunes de les dades que motiven el relativisme han estat posades en qüestió. En el cas dels futurs contingents, per exemple, és possible argumentar que no és cert que per tal d'avaluar la proposició expressada calga esperar a un moment determinat: qualsevol teoria externista sobre el significat lingüístic pot apel-lar a la metasemàntica i dir que els fets futurs determinen el contingut de les emissions presents (BaLl, pendent de publicació). Així, una emissió de (23) feta el sis d'octubre expressarà que el dia set d'octubre hi haurà una batalla naval, i aquesta proposició pot ser vertadera ja el mateix dia sis, tot i que encara no en tinguem accés a les condicions de veritat. Una cosa semblant podem dir dels enunciats amb adverbis modals com "potser" (MacFarlane 2008; SCHAFFER 2008):

(24) Joanot: "Potser Ausiàs siga a la facultat"

- Isabel: "No, t'equivoques: m’ha trucat adés per dir-me que hui estava malalt i que es quedaria a casa"

La manera habitual de tractar el significat de "potser" és la contextualista: "potser Ausiàs siga a la facultat" és vertadera si i sols si la informació de què $A$ disposa és compatible amb que Ausiàs siga a la facultat, on $A$ és el parlant. Els 
relativistes (notablement MACFARLANe 2008) addueixen que aquesta manera de tractar "potser" faria impossible la conversa (24): com podria Isabel negar el que Joanot ha asseverat? Al capdavall, el que aquesta emissió expressa és cert: que Ausiàs haja anat a la facultat no és incompatible amb l'evidència de què Joanot disposa. Addicionalment, Joanot mateix pot, més endavant, penedir-se de la seua pròpia afirmació i negar-la (ço és, pot continuar la conversa dient "Tens raó, aleshores no hi pot ser"), cosa que amb l'anàlisi contextualista no sembla possible. La solució relativista és la d'incloure al context d'avaluació un paràmetre d'informació disponible: l'emissió de Joanot a (24) serà vertadera en ser avaluada d'acord amb la informació de què Joanot disposa en eixe mateix moment, però falsa si se l'avalua d'acord amb un paràmetre d'informació distint. És per això que el que Joanot diu és vertader quan ho avalua en el seu propi context, però al mateix temps Isabel es troba en posició de negar-ho, i potser Joanot mateix també ho podrà negar quan adquirisca més informació (ço és, quan el seu context d'avaluació canvie).

El contextualista, però, pot donar una resposta molt similar a la que havíem considerat per a l'enunciat de les batalles navals: des d'una perspectiva externista, el contingut d'una emissió pot estar determinat per fets posteriors a la mateixa, com ara el fet que més endavant hom estiga disposat a penedir-se'n (BALl, pendent de publicació). Per exemple, és ben natural que la conversa en (24) continue amb Joanot dient "Tens raó, aleshores segur que no hi és", i que Hèlena continue (21b) amb "Tens raó, no ho són”. Aquestes disposicions dels parlants poden comptar com a part de la metasemàntica, ço és, com a negociacions metalingüístiques, i en conseqüència poden determinar que les emissions originals de Joanot i Hèlena siguen en realitat falses en comptes de vertaderes. Açò soscava la motivació inicial del relativisme: a (21b) i a (24) no hi ha realment desacord sense culpa, sinó un simple desacord on un parlant contradiu l'altre. D'altra banda, tant el contextualista com el minimista tenen oberta la possibilitat d'explicar (24) per una via alternativa: hom pot dir que el que Isabel està negant en (24) no és pas el contingut explícit de l'emissió d'Ausiàs, sinó més aviat alguna mena de contingut implícit ${ }^{20}$.

Hi ha molts altres tipus d'expressions per als quals s'han desenvolupat propostes relativistes, $\mathrm{i}$ fins $\mathrm{i}$ tot hi han autors que han proposat de relegar a la post-semàntica el tractament de les expressions díctiques: Santorio (20 I 2)

${ }^{20}$ Considereu el següent intercanvi:

— Joanot: "Saps si Ausiàs ha vingut?"

- Isabel: "No"

Hom pot demanar-se si en aquest intercanvi el que Isabel nega és el contingut semàntic de l'emissió de Joanot o alguna mena de contingut implícit; en el primer cas, Isabel ha dit que no sap si Ausiàs ha vingut, $\mathrm{i}$ en el segon el que ha asseverat és que Ausiàs no ha vingut. El que ocorre a (24) pot ser una cosa semblant. 
planteja que els pronoms són variables i que la funció d'assignació que els dóna un valor cal localitzar-la al context d'avaluació, i Nowak (pendent de publicació) fa el moviment anàleg a l'hora de tractar els demostratius; en la seua proposta el context d'emissió ni tan sols determina quina és aquesta funció. Aquestes i altres qüestions han contribuït a revifar una versió del vell relativisme, ara convertit en un debat de caire lingüístic.

\section{QUÈ ÉS EL CONTINGUT?}

El minimisme, el contextualisme i el relativisme són tres les tres principals postures dins del debat sobre com establir la divisió entre semàntica $\mathrm{i}$ pragmàtica. El minimisme postula l'existència d'un contingut mínim que podem avaluar com a vertader o fals i que pot ser recuperat mitjançant operacions formals sense més influència del context que la requerida per l'enunciat mateix; el contextualisme, en les seues diverses vessants, troba que aquestes proposicions mínimes no van enlloc i proposa tot un seguit d'estratègies per enriquir-ne el contingut contextualment; el relativisme, per la seua banda, accepta una noció semblant a la de contingut mínim expressat per totes les emissions d'un enunciat, però considera que per tal d'avaluar aquest contingut com a vertader $o$ fals encara cal trobar un paràmetre adient.

Tota aquesta discussió gira al voltant de dues nocions clau, "contingut" i "context", que no són gaire clares. Els contexts sovint són entesos com a constructes teòrics mitjançant els quals es modelen diversos fenòmens, però la relació que mantenen amb la realitat no és immediata: no està gens clar que aquestes col-leccions de paràmetres que els teòrics fan servir representen realment contexts d'emissió, en el sentit de l'escenari on efectivament té lloc un acte físic consistent a emetre un enunciat. Per exemple, en alguns casos sembla més apropiat concebre aquests constructes com una representació dels paràmetres que són fixats per les intencions del parlant (Predelli 1998; 20 I 2) o per l'escenari físic on l'oïdor rep l'emissió (Sidelle i99I). En qualsevol cas, no sembla que la manera com s'hagen d'obtindre aquests paràmetres siga part de la semàntica com a tal, la qual més aviat s'ocupa de què ocorre un cop han estat fixats. D'altra banda, sembla difícil modelar els contexts del contextualisme com a simples col.leccions de paràmetres; Recanati (200I), per exemple, troba que aquesta mena de constructes poden ser, com a molt, una part de la noció més rica i general de context pragmàtic.

La noció de contingut és encara més fosca, i jo diria que més rellevant per a la discussió. La caracterització que n’hem oferit a la primera secció el presenta com la informació transmesa per un enunciat, allò asseverat o allò dit. 
Sovint se l'identifica també amb les creences comunicades o el contingut dels estats mentals. Tanmateix, hi ha diversos problemes amb aquestes maneres de concebre'l.

En primer lloc, no està gens clar per què la informació transmesa hauria de ser identificada amb un conjunt de mons possibles. Aquesta noció clàssica de proposició és l'habitual en epistemologia o filosofia de la ment, però d'entrada no hi ha cap raó per donar-li cap paper preponderant en semàntica o pragmàtica: els mons possibles poden resultar útils a l'hora de modelar el significat dels morfemes de mode o dels verbs i adverbis modals, però les raons per les quals els necessitem són les mateixes que podríem adduir per als instants de temps, que resulten imprescindibles per tractar els díctics temporals i els morfemes de temps, o per als individus, que són indispensables per al tractament dels pronoms i dels morfemes personals. Hom pot, doncs, demanar-se per què allò asseverat hauria de correspondre's amb conjunts de mons possibles i no amb conjunts de parells que consten d'un món i un temps, o amb conjunts de triplets conformats per un món, un temps i un individu ${ }^{21}$. En aquest sentit, els relativistes semblen haver encertat bastant.

Una segona raó és que ni tan sols està gens clar que la semàntica haja d'ocupar-se d'una noció com la de contingut, entenent aquest com a informació comunicada (Lewis I980; NinAN 20IO; RABERN 20 I 2; YALCIN 20I4; RABERN i BALL 20I9). Si entre els objectius de la semàntica hi ha el d'esdevindre una part més de l'estudi del llenguatge juntament amb la sintaxi, la fonètica o la morfologia, aleshores els models que fa servir han de ser entesos com a models de la capacitat humana per al llenguatge (Yalcin 20I8), i més específicament d'una part del coneixement del llenguatge, en el sentit de Chomsky (1986). La possessió d'aquesta capacitat no té per què correspondre's amb l'habilitat de ser un bon comunicador, entesa com la capacitat de transmetre continguts de manera eficient. Més rellevantment, per tal de modelar la manera com els parlants són capaços de generar i copsar enunciats que mai abans havien escoltat és plausible d'assumir que la semàntica del llenguatge natural ha de ser composicional, però la noció de contingut emprada per la majoria de teories no sembla ser-ho ${ }^{22}$. Si la composicionalitat és una noció que ha de guiar

${ }^{21}$ Neale (2006) argumenta que no hi ha cap motiu per afavorir uns paràmetres sobre els altres. Vegeu Schaffer (2012) per a una discussió de les analogies entre els dominis modal i temporal en les proposicions.

${ }^{22}$ Per exemple, per tal de tractar composicionalment la quantificació en el llenguatge natural hom necessita assignar a les expressions valors semàntics que varien arreu de les funcions d'assignació (RABERN 20I3). La majoria de les teories tracten el contingut com funcions de mons possibles o de mons possibles i instants de temps, i no sembla gaire atractiu d'afegir les funcions d'assignació entre aquests paràmetres: quin trellat té que la proposició expressada siga vertadera depenent del món possible, instant de temps i funció d’assignació en què se l'avalue? 
la recerca en la semàntica i els continguts no són composicionals, quina podria ser la raó per tractar-los-hi?

Ja hem esmentat que els minimistes contemporanis, contràriament als seus predecessors, també rebutgen la idea que la semàntica haja d'ocupar-se d'assumptes que tenen a vore amb la comunicació, tot i que ho fan per motius distints. Així doncs, és ben possible que el contextualisme tinga raó en refusar d'identificar la noció minimista de contingut, que es correspon amb les proposicions mínimes, amb la informació asseverada per una emissió. Tanmateix, tampoc no està clar que la noció de contingut plantejada pels contextualistes, que es correspon amb una proposició contextualment enriquida, siga una noció requerida per la semàntica, sinó que més aviat sembla pròpia d'una teoria general de la comunicació. Ara bé, si açò és així sembla que no tenim cap mena de raó per incorporar a la semàntica una noció com la de proposició mínima: si no es correspon amb la informació transmesa i tampoc no juga cap paper en determinar composicionalment el valor semàntic de les expressions, quina necessitat hi ha de postular-la?

$\mathrm{Al}$ meu parer sí que hi ha raons importants per mantindre a la semàntica una noció com aquesta, tot i que jo proposaria d'incorporar-la-hi d'una manera una mica diferent. Vet ací el motiu: tal com hem explicat, la noció de contingut a l'estil del minimisme o del relativisme és necessària per tal de modelar correctament fenòmens que sí que cauen dins l'abast de la semàntica, com ara l'el-lipsi, l'anàfora, l'analiticitat o la cancel-labilitat, i potser també la conseqüència lògica. Certament, resultaria del tot sorprenent que la mateixa noció que serveix per explicar aquests fenòmens coincidira amb la que una teoria de la comunicació faria servir per modelar la transmissió d'informació, o amb la noció amb què epistemòlegs i filòsofs de la ment modelen les creences i els estats mentals. Açò, però, no vol dir que els contextualistes radicals tinguen raó quan asseveren que el contingut contextualment no enriquit no té cap mena de rellevància psicològica: el fet que els parlants no hi tinguen accés de manera conscient no vol dir que la capacitat de processar proposicions mínimes no jugue cap rol dins la capacitat del llenguatge; establint una analogia, els parlants no tenen accés conscient a les formes fonètiques dels enunciats, i tanmateix ningú no diria que aquestes no representen i expliquen trets psicològics.

El contingut, doncs, pot servir com a noció teòrica per modelar fenòmens que tenen a vore amb la facultat humana per al llenguatge, la qual forma part de la psicologia humana. Cal concebre'l, però, com un terme teòric propi de la semàntica la relació del qual amb nocions similars a altres disciplines està lluny de resultar òbvia, i açò comporta que els parlants no tenen per què tindre-hi accés conscient, ja que el que estem modelant és un parlant idealitzat. Així doncs, el que ens cal és, al meu parer, un concepte de contingut despullat 
de connotacions metafísiques, formalment tractable i amb una variació contextual mínima, com el del relativisme estàndard o el de la versió més laxa del minimisme. El fet mateix d'utilitzar el mot "contingut" pot haver esdevingut una font de confusió pel que fa com concebre'l, de la mateixa manera que pot haver ocorregut $\mathrm{amb}$ altres mots amb contraparts a altres àmbits del coneixement, com ara "món possible", "context" o, fins i tot, "veritat". La càrrega filosòfica d'aquestes nocions pot haver estat un llast per al debat: en la mesura que sovint contextualistes, relativistes i minimistes les conceben de manera distinta, és possible que fins ara no hagen estat realment en desacord, sinó més aviat mantenint un diàleg de sords. 


\section{BIBLIOGRAFIA}

BACH, K. I994, "Conversational impliciture”, Mind \& Language 9: 124-62.

BaCH, K. 200 I, "You Don't Say?”, Synthese 128: 15-44.

BACH, K. 2007, "The Excluded Middle: Minimal Semantics without Minimal Propositions," Philosophy and Phenomenological Research 73 (2): 435-42.

BACH, K. (manuscrit-a), "Minimalism for Dummies: a Reply to Cappelen and

Lepore", disponible a http://userwww.sfsu.edu/kbach/replytoC\&L.pdf.

BaCH, K. (manuscrit-b), "From the Strange to the Bizarre: Another Reply to Cappelen and Lepore", disponible a http://userwww.sfsu.edu/kbach/reply2toC\&L. pdf.

Ball, D. 20I7, "What Are We Doing when We Theorize about Context Sensitivity?", The Routledge Handbook of Epistemic Contextualism, J. J. IcHIKAWA (ed.), Abingdon: Routledge, 105-18.

Ball, D., "Relativism, Metasemantics, and the Future", pendent de publicació a Inquiry.

Barlew, J. 2017, The Semantics and Pragmatics of Perspectival Expressions in English and Bulu: The Case of Deictic Motion Verbs, tesi doctoral, The Ohio State University.

Barwise, J. i Perry, J. I983, Situations and attitudes, Cambridge (Massachusetts): MIT Press.

Bezuidenhout, A. 2002, "Truth-Conditional Pragmatics", Philosophical Perspectives 16: 105-34.

Bezuidenhout, A. i Cooper Cutting, J. 2002. "Literal meaning, minimal propositions, and pragmatic processing", Journal of Pragmatics 34: 433-56.

Borg, E. 2004, Minimal Semantics, Òxford: Oxford University Press.

Borg, E. 20io, "Semantics and the Place of Psychological Evidence", SAwyer, S. (ed.), New Waves in Philosophy of Language, Basingstoke: Palgrave Macmillan, $24-40$.

Borg, E. 20 12, Pursuing Meaning, Òxford: Oxford University Press.

Breheny, R.; Katsos, N. i Williams, J. 2006, “Are Generalised Scalar Implicatures Generated by Default? An On-Line Investigation into the Role of Context in Generating Pragmatic Inferences", Cognition 100: 434-63.

Cappelen, H. i Lepore, E. 2002, "Indexicality, binding, anaphora and a priori truth", Analysis 62 (4): 271-81.

Cappelen, H. i Lepore, E. 2005, Insensitive Semantics: a defense of semantic minimalism and speech act pluralism, Òxford: Blackwell.

Cappelen, H. i Lepore, E. 2006, "Reply to Bach", Philosophy and Phenomenological Research 73: 469-73. 
Cappelen, H. i Lepore, E. (manuscrit), "Kent Bach on Minimalism for Dummies", disponible a http://hermancappelen.net/docs/KBM.pdf.

Carnap, R. 1947, Meaning and Necessity, Chicago: University of Chicago Press.

Carston, R. 2002, Thoughts and Utterances, Òxford: Blackwell.

Сномsку, N. 1986, Knowledge of Language: its Nature, Origin and Use, Nova York: Praeger Publishers.

Chomsky, N. 1995, El Programa Minimista: els Escrits de Chomsky, Barcelona: Ariel, I998.

Chomsky, N. 2000, New Horizons in the Study of Language and Mind, Nova York: Cambridge University Press.

Church, A. i95 I, "A formulation of the logic of sense and denotation", P. Henle (ed.), Structure, Method and Meaning, Nova York: The Liberal Arts Press, 3-24.

Clapp, L. 20I2, "Three challenges for indexicalism", Mind \& Language 27 (4): 435-65.

Frege, G. I 892, "Über Sinn und Bedeutung", Zeitschrift für Philosophie und philosophische Kritik 100: 25-50

Glanzberg, M. 2014, "On Explanation and Partiality in Semantic Theory", A.

Burgess i B. Sherman (eds.), Metasemantics; New Essays on the Foundations of Meaning, Nova York: Oxford University Press, 259-92.

Grice, H. P. I961, “The Causal Theory of Perception”, Proceedings of the Aristotelian Society, Supplementary Volume 35: 121-52.

Grice, H. P. i975, "Logic and conversation”, P. Cole i J. Morgan (ed.), Syntax and Semantics, 3: Speech Acts, Nova York: Academic Press, 41-58.

Heim, I. i Kratzer, A. I998, Semantics in Generative Grammar, Oxxford: Blackwell.

ICHIKaWA, J. J. (ed.) 20I7, The Routledge Handbook of Epistemic Contextualism, Abingdon: Routledge.

Jaszczolt, K. M. 2007, “On Being Post-Gricean”, R. A. Nilsen; N. A. A. Amfo, i K. Borthen (ed.), Interpreting Utterances: Pragmatics and Its Interfaces, Oslo: Novus, 21-38.

Kaplan, D. I977, "Demonstratives", Almog, J. et al. (ed.), Themes from Kaplan, Òxford: Oxford University Press, I989, 481-564.

Kennedy, C. i Mcnally, L. 2oio, "Color, context, and compositionality", Synthese 174: 79-98.

KRIPKE, S. I959, "A Completeness Theorem in Modal Logic", Journal of Symbolic Logic, 24 (1): 1-14.

Kripke, S. I963A, "Semantical Analysis of Modal Logic I: Normal Modal Propositional Calculi", Zeitschrift für Mathematische Logik und Grundlagen der Mathematik 9: 67-96.

Kripke, S. I963в, "Semantical Considerations on Modal Logic", Acta Philosophica Fennica 16: 83-94. 
Kripke, S. I972, Naming and Necessity, Òxford: Basil Blackwell, I980.

Kratzer, A. I998, "More structural analogies between tenses and pronouns", D. Strolovitch i A. Lawson, Proceedings of SALT VIII, 92-110.

Lasersohn, P. 2005, "Context Dependence, Disagreement, and Predicates of Personal Taste", Linguistics and Philosophy 28 (6): 643-86.

Lewis, D. I980, "Index, context and content", S. Kanger i S. Öhman (ed.), Philosophy and Grammar, Reidel Publishing, 79-100.

MacFarlane, J. 2003A, "Future Contingents and Relative Truth", Philosophical Quarterly 53: 321-36.

MacFarlane, J. 2003в, "Three Grades of Truth Relativity", manuscrit disponible a https://johnmacfarlane.net/3grades.pdf.

MacFarlane, J. 2005, "Making Sense of Relative Truth", Proceedings of the Aristotelian Society 105: 321-39.

MacFarlane, J. 2007, "Semantic Minimalism and Nonindexical Contextualism", G. Preyer i G. Peter (ed.), Context-Sensitivity and Semantic Minimalism: New Essays on Semantics and Pragmatics, Nova York: Oxford University Press, 240-50.

MacFarlane, J. 2008, "Epistemic Modals are Assessment-Sensitive", B. Weatherson i A. Egan (ed.), Epistemic Modality, Òxford: Oxford University Press, 144-78.

Marcus, R. 1946, "A Functional Calculus of First Order Based on Strict Implication", The Journal of Symbolic Logic 11: 1-16.

Montague, R. i970, "Universal Grammar", Theoria 36: 373-98.

Neale, S. 2006, "Ontological Symmetry in Language: a Brief Manifesto", Mind \& Language 21 (4): 504-39.

Ninan, D. 2010, "Semantics and the Objects of Assertion", Linguistics and Philosophy 33 (5), 355-80.

NowaK, E., "No context, no content, no problem", pendent de publicació a Mind \& Language.

Partee, B. 1973, "Some structural analogies between tenses and pronouns in English", The Journal of Philosophy LXX (18): 601-9.

Perry, J. I996, "Thought without Representation", Proceedings of the Aristotelian Society Supplementary Volume 60: 263-83.

Predelli, S. 2005A, Contexts. Meaning, Truth, and the Use of Language. Òxford: Oxford University Press.

Predelli, S. 2005B, "Painted Leaves, Context and Semantic Analysis", Linguistics and Philosophy 28, 351-74.

Predelli, S. I998, "I am not here now”, Analysis 58 (2): 107-15.

Predelli, S. 20 1 2, "Indexicality, Intensionality, and Relativist Post-Semantics", Synthese 184 (2): 121-36. 
Predelli, S. i Stojanovic, I. 2008, "Relativism and the Logic of Indexicals", M. Kölbel i M. Garcia-Carpintero (ed.), Relative Truth, Òxford: Oxford University Press, 63-79.

Pustejovsky, J. 1995, The generative lexicon, Cambridge: MIT Press.

RABERN, B. 201 2, "Against the identification of assertoric content with compositional value", Synthese 189: 75-96.

Rabern, B. 2013, "Monsters in Kaplan's LD”, Philosophical Studies 164: 393404.

Rabern, B. i Ball, D. 2019, "Monsters and the Theoretical Role of Context", Philosophy and Phenomenological Research 98 (2): 392-416.

Recanati, F. 200I, "What is said", Synthese 198: 75-91.

Recanati, F. 2004, Literal Meaning, Cambridge: Cambridge University Press.

Richard, M. I993, "Attitudes in Context", Linguistics and Philosophy 16 (2): $123-48$.

Rothschild, D. i Segal, G. 2009, "Indexical predicates”, Mind \& Language 24: 467-93.

Santorio, P. 2012, "Reference and monstrosity", Philosophical Review 121 (3): $359-406$

SAul, J. 2002, "What is Said and Psychological Reality: Grice's Project and Relevance Theorists' Criticisms", Linguistics and Philosophy 24, 347-72.

SAul, J. 2013, Lying, Misleading and the Role of What is Said, Oxford: Oxford University Press.

Schaffer, J. 2008, "Perspective in Taste Predicates and Epistemic Modals", B. Weatherson i A. Egan (ed.), Epistemic Modality, Òxford: Oxford University Press, 179-226.

Schaffer, J. 20 r 2, “Necessitarian Propositions”, Synthese 189 (1): 119-62.

Searle, J. 1978, "Literal Meaning”, Erkenntnis 13: 207-24.

Searle, J. i980a, "The Background of Meaning”, J. Searle; F. Kiefer i M. Bierwisch (ed.), Speech-act theory and pragmatics, Dordrecht: Reidel, 221-32.

Searle, J. I980в, "Minds, Brains and Programs", Behavioral and Brain Sciences 3 (3): 417-57.

Sidelle, A. I99I, “The answering machine paradox", Canadian Journal of Philosophy 21: 525-39.

SoAmes, S. 2002, Beyond Rigidity, Òxford: Oxford University Press.

Sperber, D. i Wilson, D. I986, Relevance: Communication and Cognition, Cambridge (Massachusetts): Harvard University Press.

Sperber, D. i Wilson, D. 20 I 2, Meaning and Relevance, Nova York: Cambridge University Press.

Stanley, J. i Szabó, Z. 200o, "On quantifier domain restriction”, Mind and Language 15, 219-61. 
Stojanovic, I. 2007, "Talking about taste: disagreement, implicit arguments, and relative truth", Linguistics and Philosophy 30 (2): 691-706.

Stojanovic, I. 2008, "The Scope and the Subtleties of the Contextualism/Literalism/Relativism Debate", Language and Linguistics Compass 2 (6): 1171-88.

Szabó, Z. 200 I, "Adjectives in context", I. Kenesei i R. M. Harnish (ed.), Perspectives on Semantics Pragmatics and Discourse: A Festschrift for Ferenc Kiefer, Amsterdam: John Benjamins, 119-46.

Travis, C. 1977, "Pragmatics", B. Hale i C. Wright (ed.), A Companion to the Philosophy of Language, Òxford: Blackwell, 187-229.

Travis, C. 1985 , "On what is strictly speaking true", Canadian Journal of Philosophy 15: 187-229.

Travis, C. I991, "Annals of analysis: Studies in the Way of Words, by H. P. Grice", Mind 100: 237-64.

Westerstånl, D. 20 I2, "Compositionality in Kaplan-style semantics", The $O x$ ford handbook of compositionality, W. Hinzen et al. (ed.), Òxford: Oxford University Press, 192-219.

Williams, M. I99I, Unnatural Doubts: Epistemological Realism and the Basis of Skepticism, Cambridge (Massachusetts): Blackwell.

Williamson, T. 2005, "Contextualism, subject-sensitive invariantism and knowledge of knowledge”, Philosophical Quaterly 55: 213-35.

YalCIN, S. 2014, "Semantics and metasemantics in the context of generative grammar", A. Burgess i B. Sherman (ed.), Metasemantics; New Essays on the Foundations of Meaning, Nova York: Oxford University Press, 17-54.

Yalcin, S. 2018, "Semantics as a Model-Based Science", B. Rabern i D. Ball (ed.), The Science of Meaning. Essays on the Metatheory of Natural Language Semantics, Nova York: Oxford University Press, 334-60. 
